\title{
POU domain family values: flexibility, partnerships, and developmental codes
}

\author{
Aimee K. Ryan and Michael G. Rosenfeld ${ }^{1}$ \\ Howard Hughes Medical Institute, Department and School of Medicine, University of California at San Diego, \\ La Jolla, Califiornia 92093-0648 USA
}

Transcription factors serve critical roles in the progressive development of general body plan, organ commitment, and finally, specific cell types. It has been the hope of most developmental biologists that comparison of the biological roles of a series of individual members within a family will permit at least some predictive generalizations regarding the developmental events that are likely to be regulated by a particular class of transcription factors. Here, we present an overview of the developmental functions of the family of transcription factors characterized by the POU DNA-binding motif afforded by recent in vivo studies.

The POU domain family of transcription factors was defined following the observation that the products of three mammalian genes, Pit-1, Oct-1, and Oct-2 and the protein encoded by the Caenorhabditis elegans gene unc-86 shared a region of homology, known as the POU domain (Bodner et al. 1988; Clerc et al. 1988; Finney et al. 1988; Herr et al. 1988; Ingraham et al. 1988; Ko et al. 1988; Müller et al. 1988; Scheidereit et al. 1988; Sturm et al. 1988). The POU domain is a bipartite DNA-binding domain (Sturm and Herr 1988; Ingraham et al. 1990; Botfield et al. 1992; Verrijzer et al. 1992), consisting of two highly conserved regions tethered by a variable linker. The -75 -amino acid amino-terminal region was called the POU-specific domain and the carboxy-terminal 60amino acid region, the POU homeodomain.

POU domain proteins have been identified from a diverse range of species (Table 1). Although currently grouped into six or seven classes based on the amino acid sequence of their POU domains and conservation of the variable linker region (Wegner et al. 1993a), the recent identification and characterization of several new POU domain proteins suggests that some classes may be further subdivided (Spaniol et al. 1996). The in vivo functions of many POU proteins have been examined through targeted gene disruption in the mouse and characterization of loss-of-function and gain-of-function mutations in Drosophila, C. elegans, and Xenopus. These in vivo studies demonstrate that POU domain proteins regulate key developmental processes and will be the

${ }^{1}$ Corresponding author.

E-MAIL mrosenfeld@ucsd.edu; FAX (619) 534-8180. primary focus of this review. Crystallization of the Oct-1 and Pit-1 POU domains on DNA and in vitro studies examining the specificity of POU domain cofactor interactions suggest that the flexibility with which the POU domain recognizes DNA-binding sites is a critical component of its ability to regulate gene expression. The implications of these data with respect to the mechanisms utilized by the POU domain family of transcription factors to control developmental events will also be discussed.

\section{Conformation of the POU domain on DNA}

High-affinity site-specific DNA binding by POU domain transcription factors requires both the POU-specific domain and the POU homeodomain (Sturm and Herr 1988; Ingraham et al. 1990; Kristie and Sharp 1990; Verrijzer et al. 1990, 1992). The two subdomains can cooperatively bind DNA even when they are not joined by the linker (Klemm and Pabo 1996). Resolution of the crystal structures of Oct-1 and Pit-1 POU domains bound to DNA as a monomer and homodimer, respectively, confirmed several of the in vitro findings regarding interactions of this bipartite DNA-binding domain with DNA and has provided important information regarding the flexibility and versatility of POU domain proteins (Klemm et al. 1994; Jacobson et al. 1997).

\section{Structure of Oct-1 bound to an octamer DNA-binding site}

Overall the crystal structure of a monomer of the Oct-1 POU domain bound to the octamer element was similar to that predicted by the nuclear magnetic resonance (NMR) solution structures of the POU-specific domain (Assa-Munt et al. 1993; Dekker et al. 1993) and the POU homeodomain (Sivaraja et al. 1994; Cox et al. 1995; Morita et al. 1995) in isolation. The POU-specific domain consists of four $\alpha$ helices, with the second and third helices forming a structure similar to the helix-turnhelix motif of the $\lambda$ and 434 repressors; several of the DNA base contacts are also conserved (Klemm et al. 1994). Although the primary sequence of the Oct-1 POU homeodomain is considerably divergent from those of classic homeodomains, it is structurally conserved and 
Table 1. Summary of expression patterns and biological functions of POU domain proteins

\begin{tabular}{|c|c|c|c|c|}
\hline Class & Factor $^{\mathrm{a}}$ & & Expression pattern & Function \\
\hline I & Pit-1 & {$[\mathrm{M}]$} & $\begin{array}{l}\text { anterior pituitary gland-- } \\
\text { somatotropes, lactotropes, } \\
\text { thyrotropes }\end{array}$ & $\begin{array}{l}\text { determination of somatotrope, } \\
\text { lactotrope and thyrotrope lineages } \\
\text { cell proliferation/survival }\end{array}$ \\
\hline \multirow[t]{10}{*}{ II } & $\begin{array}{l}\text { Oct-1 (Otf-1, NF-A1, } \\
\text { POU } 2 F 1)\end{array}$ & {$[\mathrm{M}]$} & ubiquitous & potentially lethal $^{\mathrm{b}}$ \\
\hline & Xoct-1 & {$[\mathrm{X}]$} & & \\
\hline & SpOct & [S] & oogenesis and early embryo & $\begin{array}{l}\text { antisense blocks protein } \\
\text { accumulation in embryo }\end{array}$ \\
\hline & Pdm-1 (nubbin, dpou-19) & [D] & both: gap-like pattern in early & Pdm-1 and Pdm-2-Cell fate \\
\hline & Pdm-2 (miti-mere, dpou-28) & {$[\mathrm{D}]$} & $\begin{array}{l}\text { embryo; peripheral sensory organs; } \\
\text { neuroectoderm, neuroblasts; }\end{array}$ & $\begin{array}{l}\text { specification in NB4 neuroblast } \\
\text { lineage }\end{array}$ \\
\hline & & & ectoderm; & Pdm-1-proliferation in wing; \\
\hline & & & $\begin{array}{l}\text { Pdm-1 only—-throughout wing } \\
\text { primordium }\end{array}$ & $\begin{array}{l}\text { functions in hinge region of wing } \\
\text { disc }\end{array}$ \\
\hline & $\begin{array}{l}\text { Oct-2 (Otf-2, NF-A2, } \\
\text { POU2F2) }\end{array}$ & {$[\mathrm{M}]$} & $\begin{array}{l}\text { B cells; alternative splice forms in } \\
\text { nervous system }\end{array}$ & $\begin{array}{l}\text { neonatal lethal; terminal } \\
\text { differentiation of } \mathrm{B} \text { cells is affected }\end{array}$ \\
\hline & $\begin{array}{l}\text { Skn-1a/i } \mid \text { Oct-11, Epoc-1, } \\
\text { Otf-11, Pou2F3| }\end{array}$ & {$[\mathrm{M}]$} & skin (keratinocytes) & differentiation and wound healing ${ }^{\mathrm{c}}$ \\
\hline & Xnrl-16/21 & {$[\mathrm{X}]$} & & \\
\hline \multirow[t]{15}{*}{ III } & Brn-1 (Otf-8, POU3F3\} & {$[\mathrm{M}]$} & $\begin{array}{l}\text { all levels of CNS in embryo and } \\
\text { adult-more restricted in adult; } \\
\text { intestine, kidney }\end{array}$ & not reported \\
\hline & zp-12 & {$[\mathrm{Z}]$} & overlapping expression in embryonic & not reported \\
\hline & sp-23 (zfpoul) & {$[\mathrm{Z}]$} & and adult nervous system; & \\
\hline & zpbrain 1.1 & {$[\mathrm{Z}]$} & pronephric Wolffian duct & \\
\hline & $\begin{array}{l}\text { Brn-2 (Otf-7, N-Oct-3, } \\
\text { POU3F2) }\end{array}$ & {$[\mathrm{M}]$} & $\begin{array}{l}\text { all levels of CNS in embryo and } \\
\text { adult-more restricted expression in } \\
\text { adult }\end{array}$ & $\begin{array}{l}\text { postnatal lethal } \\
\text { terminal differentiation and survival } \\
\text { of supraoptic and paraventricular } \\
\text { hypothalamic nuclei }\end{array}$ \\
\hline & zp-47 & {$[\mathrm{Z}]$} & all levels of CNS in embryo and adult & not determined \\
\hline & brain 1.2 & {$[\mathrm{Z}]$} & all levels of CNS in embryo and adult & not determined \\
\hline & XLPOU 3 & {$[\mathbf{X}]$} & not described & \\
\hline & $\begin{array}{l}\text { Brn-4 (RHS2, N-Oct-4, } \\
\text { POU3F4, Oft-9) }\end{array}$ & {$[\mathrm{M}]$} & $\begin{array}{l}\text { all levels of CNS in embryo and } \\
\text { adult, pancrease, Rathke's pouch, } \\
\text { whiskers, otic vesicle }\end{array}$ & not reported \\
\hline & XLPOU 2 & {$[\mathrm{M}]$} & $\begin{array}{l}\text { Spemann's organizer, mesoderm in } \\
\text { gastrula, neuroectoderm, neural } \\
\text { plate, notochord, brain }\end{array}$ & $\begin{array}{l}\text { misexpression causes ectopic } \\
\text { expression of neural-specific } \\
\text { markers }\end{array}$ \\
\hline & $\begin{array}{l}\text { Tst-1/Oct-6/SCIP (Oft-6, } \\
\text { POU3F1) }\end{array}$ & {$[\mathrm{M}]$} & $\begin{array}{l}\text { all levels of CNS, oligodendrocyte } \\
\text { precursors, Schwann cells, testes, } \\
\text { skin }\end{array}$ & $\begin{array}{l}\text { postnatal lethal; checkpoint control in } \\
\text { peripheral myelination; terminal } \\
\text { differentiation including migration }\end{array}$ \\
\hline & $\mathrm{zp} 50^{\mathrm{d}}$ & {$[\mathrm{Z}]$} & $\begin{array}{l}\text { CNS: dynamic and complex } \\
\text { expression during embryogenesis }\end{array}$ & \\
\hline & $\begin{array}{l}\text { Cf1a/drifter/ventral } \\
\text { veinless }\end{array}$ & [D] & $\begin{array}{l}\text { Tracheal placodes; midline glia, wing } \\
\text { disc, CNS (not neuroblasts), hindgut }\end{array}$ & $\begin{array}{l}\text { embryonic: strong mutations are } \\
\text { lethal; formation of tracheal tree, } \\
\text { patterning of ventral ectoderm; } \\
\text { migration but not survival of } \\
\text { midline glia cells }\end{array}$ \\
\hline & XLPOU $1^{\mathrm{d}}$ & {$[\mathrm{X}]$} & $\begin{array}{l}3.5-\mathrm{kb} \text { transcript--brain, eyes } \\
2.5 \text {-kb transcript-skin }\end{array}$ & $\begin{array}{l}\text { proliferation and differentiation of } \\
\text { wing }\end{array}$ \\
\hline & CEH-6 & {$[\mathrm{C}]$} & & \\
\hline \multirow[t]{3}{*}{ IV } & Unc-86 & {$[\mathrm{C}]$} & nervous system & $\begin{array}{l}\text { lineage determination; terminal } \\
\text { differentiation }\end{array}$ \\
\hline & I-POU & [D] & nervous system & \\
\hline & $\begin{array}{l}\text { Brn-3.0/Brn-3a (RDC-1, } \\
\text { POU4F1) }\end{array}$ & {$[\mathrm{M}]$} & $\begin{array}{l}\text { CNS: midbrain, hindbrain, spinal cord } \\
\text { PNS: sensory ganglia }\end{array}$ & $\begin{array}{l}\text { neonatal lethal; swallowing defect; } \\
\text { uncoordinated; survival and } \\
\text { terminal differentiation of sensory } \\
\text { ganglia, compact formation of } \\
\text { nucleus ambiguus red nucleus }\end{array}$ \\
\hline
\end{tabular}


Table 1. (Continued)

\begin{tabular}{|c|c|c|c|c|}
\hline Class & Factor $^{a}$ & & Expression Pattern & Function \\
\hline & Brn-3.1/Brn-3c (POU4F3) & {$[\mathrm{M}]$} & $\begin{array}{l}\text { CNS: restricted in midbrain, } \\
\text { hindbrain and spinal cord; PNS: } \\
\text { sensory ganglia }\end{array}$ & $\begin{array}{l}\text { terminal differentiation of hair cells; } \\
\text { null mice are deaf }\end{array}$ \\
\hline & brn-3.1 & {$[\mathrm{Z}]$} & eye and brain & \\
\hline & Brn-3.2/Brn-3b (POU4F2) & {$[\mathrm{M}]$} & $\begin{array}{l}\text { CNS: midbrain, hindbrain, spinal cord } \\
\text { PNS: sensory ganglia }\end{array}$ & $\begin{array}{l}\text { terminal differentiation and survival } \\
\text { of retinal ganglion cells }\end{array}$ \\
\hline \multirow[t]{6}{*}{$\mathrm{V}$} & $\begin{array}{l}\text { Oct-3/4 (Oct-5, NF-A3, } \\
\text { POU5F1) }\end{array}$ & {$[\mathrm{M}]$} & $\begin{array}{l}\text { maternal transcript in oocyte; } \\
\text { totipotent and pluripotent cells } \\
\text { during embryogenesis; restricts to } \\
\text { primordial germ cells by Ell in } \\
\text { mouse }\end{array}$ & not reported \\
\hline & Pou $^{e}$ & {$[\mathrm{Z}]$} & $\begin{array}{l}\text { maternal transcript in oocyte; } \\
\text { pluripotent cells in embryo; neural } \\
\text { plate; rhombomeres } 2 \text { and } 4\end{array}$ & critical for early embryogenesis \\
\hline & XLPOU-60 & {$[\mathrm{X}]$} & $\begin{array}{l}\text { maternal transcript in oocyte; } \\
\text { dramatic decrease by early } \\
\text { gastrulation (peak in oocyte and } \\
\text { fertilized egg) }\end{array}$ & \\
\hline & XOct-25 & {$[\mathrm{X}]$} & $\begin{array}{l}\text { expressed from late oocyte through } \\
\text { late gastrula/early neurula; } \\
\text { expression peaks at early gastrula }\end{array}$ & \\
\hline & XLPOU-91 (oct91/oct92) & & $\begin{array}{l}\text { expressed from midblastula through } \\
\text { late neurula/early tailbud; peaks at } \\
\text { gastrulation }\end{array}$ & \\
\hline & Sprm 1 & {$[\mathrm{M}]$} & transiently in testes & subtle effects on genetic fitness \\
\hline \multirow[t]{3}{*}{ VI } & $\begin{array}{l}\text { Brn-5 (Emb, Cns-1, mPOU, } \\
\text { POU6F1) }\end{array}$ & {$[\mathrm{M}]$} & CNS: broadly expressed & not reported \\
\hline & pou[c] & {$[\mathrm{Z}]$} & $\begin{array}{l}\text { Ubiquitous during embryogenesis; } \\
\text { highest in CNS }\end{array}$ & \\
\hline & RPF-1 & {$[\mathrm{Z}]$} & $\begin{array}{l}\text { CNS: medial habenula, dorsal } \\
\text { thalamus, subset of retinal ganglion } \\
\text { and amacrine cells }\end{array}$ & not reported \\
\hline Misc. & CEH-18 & {$[\mathrm{C}]$} & Gonadal sheath cells & $\begin{array}{l}\text { oocyte development, gonadal } \\
\text { migration, epidermal differentiation } \\
\text { in L1 stage animals }\end{array}$ \\
\hline
\end{tabular}

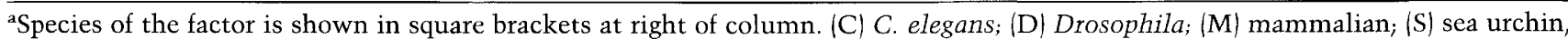
(X) Xenopus; (Z) zebrafish. References for POU domain proteins not described in body of the text: Skn-1a/i (Andersen et al. 1993b), SpOct (Char et al. 1993); zp-12, zp23, zp47 (Spaniol et al. 1996); CEH-6 (Burglin et al. 1989); RPF-1 (Zhou et al. 1996); pou[c] (Johansen et al. 1993); Brn-5 (Andersen et al. 1993c); emb (Okamoto et al, 1993); mPOU (Wey et al. 1994); Cns-1 (Bulleit et al. 1994).

${ }^{b}$ Targeted disruption of the $\mathrm{CD} 3_{\eta}$ locus affects Oct- 1 transcription, which is encoded on the opposite strand. The high mortality in newborn $\mathrm{CD}_{\eta}$ null mice is presumed to be attributable to the decrease in Oct-1 expression (Koyasu et al. 1994; Ohno et al. 1994). ${ }^{c}$ B. Anderson, W.C. Weinberg, O. Rennekampff, R.J. McEvilly, J.R. Bermingham, F. Hooshmand, J.F. Hansbrough, M.R. Pittelkow, S.H. Yuspa, and M.G. Rosenfeld (in prep.).

$\mathrm{d}_{\mathrm{zp} 50}$ and XLPOU1 are most closely related to mammalian Tst-1/Oct-6/SCIP. However, because of some variation in expression patterns, it is not certain whether they are functional homologs (Hauptmann and Gerster 1996).

${ }^{e}$ There is some debate as to whether or not Pou2 is a member of class $V$ or defines a novel class. For the purposes of this review it has been placed in class $\mathrm{V}$ because of presumed functional homology with other class $\mathrm{V}$ proteins based on spatial and temporal aspects of its expression.

docks against the DNA in a manner that is analogous to other homeodomain proteins (Klemm et al. 1994). Both the POU-specific domain and the POU homeodomain make extensive base and phosphate backbone contacts with the DNA, and as predicted by in vitro experiments (for review, see Herr and Cleary 1995), the POU-specific domain binds the $5^{\prime}$ ATGC portion of the octamer element and the POU homeodomain binds the 3' A/T-rich portion of the site (Klemm and Pabo 1994). The Oct-1 POU-specific domain and the POU homeodomain bind to opposite faces of the DNA helix, yet despite overlap- ping DNA contacts near the center of the octamer element, they do not interact (Fig. 1A).

The overlapping contacts made by the Oct-1 POU-specific domain and POU homeodomain are presumed to be important for mediating the cooperative binding of these two subdomains. Although binding site selection studies suggested that Oct-1 will recognize either an A or a $\mathrm{T}$ at position 5 in the octamer element (Verrijzer et al. 1992), an $\mathrm{A} / \mathrm{T}$ base pair at this position, as opposed to a T/A base pair, is critical for the cooperative binding of the POU-specific domain and POU homeodomain, as is the 
Figure 1. Schematic representation of the crystal structures of Oct-1 and Pit-1 bound to DNA. (A) Diagrammatic representation of the crystal structure of an Oct-1 POU domain monomer bound to an octamer element (ATGCAAAT on the lower strand). The Oct-1 POU-specific and POU homeodomains bind to opposite faces of the DNA and have a tail-to-tail orientation. The positionings of the Oct-1 POU-specific domain ( $\left.\mathrm{POU}_{\mathrm{S}}\right)$ and POU homeodomain $\left(\mathrm{POU}_{\mathrm{H}}\right)$ on the ATGC and AAAT half-sites, respectively, are diagramed on the sequence below. (B) Diagrammatic representation of a Pit- 1 POU domain homodimer bound to a dimer recognition site. The sequence contacted by the Pit-1 POU domains is an inverted palindrome, ATGTATATACAT. In contrast to the Oct-1 monomer, the Pit-1 POU-specific domain $\left(\mathrm{POU}_{\mathrm{S}}\right)$ and the POU homeodomain $\left(\mathrm{POU}_{\mathrm{H}}\right)$ in each monomer bind the DNA in a head-to-tail orientation and the linker does not cross the minor groove. The orientation of the four POU subdomains in the dimer, when bound to DNA, are indicated on the sequence below.
A
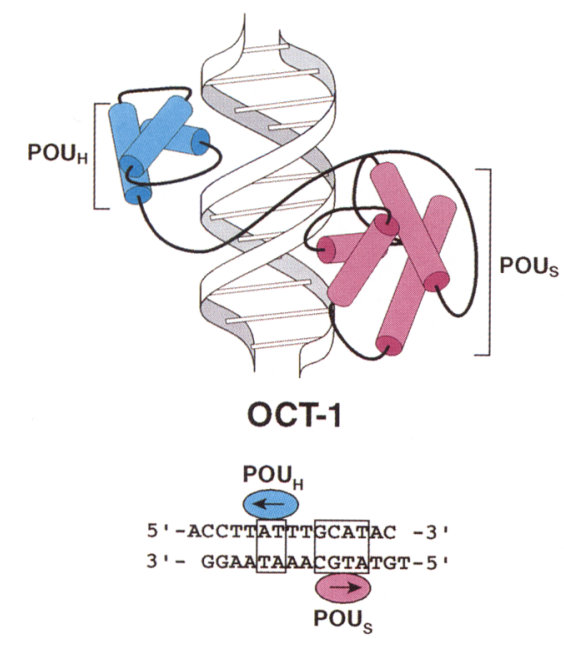

B
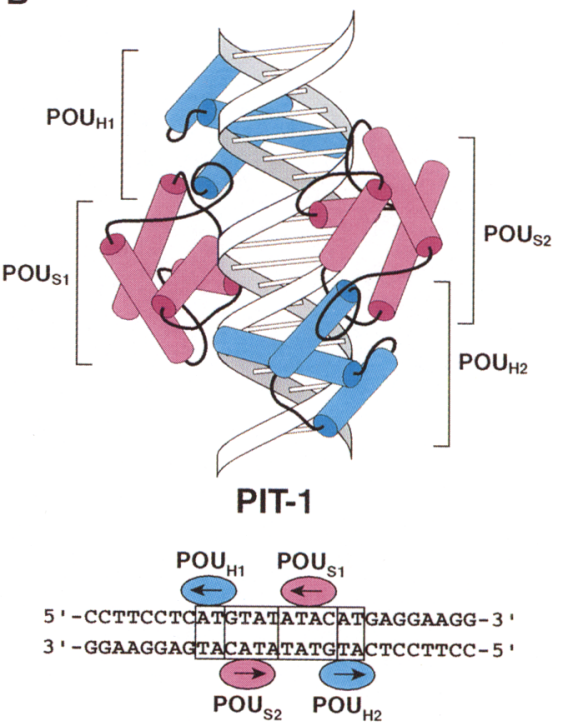

spacing of the two subsites (Klemm and Pabo 1996). Adenine is the more common base at this position in naturally occurring octamer sites within cellular promoters, suggesting that additional constraints are involved for the in vivo function of Oct-1 on octamer elements (Klemm et al. 1994).

\section{Crystal structure of a Pit-1 homodimer on DNA}

A homodimer of the Pit-1 POU domain was crystallized bound to a functional Pit-1 dimer DNA element that is closely related to a site in the proximal promoter of the prolactin gene (Jacobson et al. 1997). The structure of the Pit-1 POU domain on DNA is very similar to that of Oct-1, and the Pit-1 POU homeodomain/DNA structure is strikingly similar to that of other homeodomains, including the Oct-1 POU homeodomain. The DNA contacts made by the Pit-1 POU-specific domain are also similar to those of Oct-1 and conserved with many made by the prokaryotic repressors. In the Oct-1 crystal, the POU-specific domain recognizes a GCAT half-site, whereas the corresponding sequence recognized by the Pit-1 POU-specific domain, GTAT, is on the opposing strand. As a result, the orientation of the Pit-1 POU. specific domain relative to the POU homeodomain is flipped, as compared to the Oct- 1 crystal structure, indicating the remarkable flexibility of the POU-specific domain in adapting to variations in sequence within the site. Also in contrast to the Oct-1 monomer structure is the observation that the POU-specific and POU homeodomain of each Pit-1 molecule make major groove contacts on the same face of the DNA, consistent with the constraints imposed by its 15 -amino-acid linker. As a result, the Pit-1 POU domain homodimer essentially surrounds its DNA-binding site (Fig. 1B).

In the Pit-1 POU domain homodimer the dimerization interface is formed between the carboxy-terminal end of helix 3 of the POU homeodomain of one Pit- 1 molecule and the amino terminus of helix 1 and the loop between helices 3 and 4 of the POU-specific domain of the other Pit-1 molecule. In contrast to other homeodomain crystal structures, the carboxyl terminus of helix 3 in the Pit-1 POU homeodomain has an extended structure (Jacobson et al. 1997) as observed in the NMR solution structure of Oct-1, Oct-2, and Oct-3 POU homeodomains (Sivaraja et al. 1994; Cox et al. 1995; Morita et al. 1995). The flexibility of the carboxyl terminus of POU homeodomains may account for the relatively low affinity of the POU homeodomain for DNA in the absence of a POU-specific domain. In the Pit-1 POU domain crystal structure, this flexibility is important for dimerization. Interestingly, the most common mutation in the human Pit-1 gene that is associated with combined pituitary hormone deficiencies (R271W), maps within the dimerization interface (Radovick et al. 1992; Cohen et al. 1995).

Pit- 1 and Oct-1 are phosphorylated in vitro by protein kinase A (Kapiloff et al. 1991; Segil et al. 1991) and in vivo by a cell cycle-dependent kinase (Segil et al. 1991; Caelles et al. 1995) at position 7 of their homeodomains, Thr-220 and Ser-385, respectively. Phosphorylation of Ser-385 in Oct-1 inhibits binding to an octamer element in the histone H2B promoter (Segil et al. 1991). Although phosphorylation of the Pit- 1 homeodomain at Thr-220 is generally inhibitory to binding (Kapiloff et al. 1991; Cae- 
lles et al. 1995), the magnitude of the effect is dependent on the DNA recognition element (Kapiloff et al. 1991). The differential effects of POU homeodomain phosphorylation on DNA binding probably reflects the relative distance between the phosphoacceptor amino acids and the DNA; Ser-385 in the Oct-1 crystal is only $3.6 \AA$ from the DNA backbone (Klemm et al. 1994), whereas in the Pit-1 crystal Thr-220 is almost twice as far away from the backbone, $\sim 7 \AA$ (Jacobson et al. 1997). The difference in these distances appears to be a direct result of the degree to which Oct-1 and Pit-1 bend the DNA upon binding (Klemm et al. 1994; Jacobson et al. 1997).

\section{Function of the POU domain linker in variable DNA site recognition}

The disordered linker region observed in both the Oct-1 and Pit-1 crystal structures supports previous hypotheses that a main function of the linker is simply to tether the POU-specific and POU homeodomains, effectively increasing the local concentrations of these two subdomains, thereby aiding high-affinity, site-specific DNA binding by the POU domain. The length of the linker region, which ranges in size from 15 to 56 amino acids, is likely to play an important role in enabling the POUspecific domain to assume various orientations relative to the POU homeodomain and, consequently, in determining the versatility with which POU domains can recognize various DNA elements. For instance, some class III POU domain proteins, which have a 17 -amino-acid linker, can accommodate spacings of 0,2 , or 3 nucleotides between the DNA half-sites when the POU-specific and POU homeodomain are in one of the two possible orientations. This class of POU domain proteins can also bind with high affinity to sites where the relative orientation of the POU-specific and POU homeodomain is analogous to that of Oct- 1 on its cognate DNA site (Li et al. 1993; Certel et al. 1996; Malik et al. 1996).

\section{DNA-binding sites dictate cofactor interactions}

These considerations begin to account for the ability of POU domain proteins to recognize a diverse array of DNA-binding sites. The additional binding sites identified for several POU domain proteins are generally $\mathrm{A} / \mathrm{T}$ rich and/or variants of the octamer motif, consistent with the flexibility of orientation of the two POU domain DNA-binding motifs (for examples, see Xiang et al. 1995; Dawson et al. 1996; Malik et al. 1996; Okazawa et al. 1996; Gruber et al. 1997).

The ability of a DNA-binding site to determine POU domain coactivator interactions has been examined best for Oct-1, for which two site-dependent POU domaininteracting factors have been identified. In addition to its functions in adenovirus DNA replication and the regulation of housekeeping and temporally and spatially restricted gene expression, the ubiquitously expressed Oct-1 is required for initiation of viral gene expression in herpes simplex virus (HSV)-infected cells (for review, see Verrijzer and Van der Vliet 1993; Wegner et al. 1993a;
Herr and Cleary 1995). Upon HSV infection, the viral activator protein VP16 first interacts with the multisubunit host cell factor HCF and then associates with Oct-1 but only when it is bound to a TAAT motif flanked by GARAT $(\mathrm{R}=$ purine $)$, in the presence $\left(\mathrm{OCTA}^{+}\right)$ TAATGARAT, or absence $\left(\mathrm{OCTA}^{-}\right)$TAATGARAT of an octamer element (Gerster and Roeder 1988; Kristie et al. 1989). Alone, VP16 does not effectively bind DNA, and whether or not VP16 contacts DNA in the context of the Oct-1/VP16/HCF complex remains controversial (Kristie and Sharp 1990; Stern and Herr 1991; Walker et al. 1994). However, it is clear that the presence of a GARAT flanking region alters the conformation of Oct-1 on DNA and permits its interaction with VP16 (Walker et al. 1994; Cleary and Herr 1995). The POU homeodomain always recognizes the TAAT portion of the site, whereas the POU-specific domain exhibits flexibility in binding and seemingly is able to contact either the GARAT or, in the case of $\left(\mathrm{OCTA}^{+}\right)$TAATGARAT elements, the ATGC in the octamer site. An additional layer of conformational specificity can be inferred by the observation that the bovine herpesvirus VP16 counterpart is able to distinguish between Oct-1 bound to a HSV TAATGARAT element and Oct-1 bound to a TAATGARAT element from a bovine herpesvirus immediate early gene (Huang and Herr 1996; Misra et al. 1996).

The recent cloning of the Oct-1/Oct-2 B cell-specific coactivator OCA-B/Bob-1/OBF-1/Gstaiger et al. 1995; Luo and Roeder 1995; Pfisterer et al. 1995; Strubin et al. 1995) has permitted further characterization of its interactions with Oct-1. The extent to which OCA-B enhances octamer-dependent transcription is promoter dependent, suggesting that sequences flanking the octamer element are important. Although full-length OCA-B does not bind DNA (Luo and Roeder 1995), its ability to interact with the Oct-1 POU-specific domain is dependent on an amino-terminal domain that contains a transferable transactivation domain that in isolation binds DNA in a sequence-specific manner (Gstaiger et al. 1995). The A/T base pair at position 5 in the ATGCAAAT octamer element is contacted by OCA-B and is critical for a functional OCA-B interaction with Oct-1, although the two half-sites could be spaced by 2 bp without disrupting the OCA-B/Oct-1/DNA complex (Cepek et al. 1996; Gstaiger et al. 1996). Interestingly, this is the same base pair that is required for cooperative DNA binding by the Oct-1 POU-specific domain and POU homeodomain (Klemm and Pabo 1996).

Site-dependent coactivator usage is likely to prove prototypic for transcriptional activation by many POU domain proteins. For instance, Oct- $3 / 4$ has two transactivation domains (Imagawa et al. 1991; Schöler et al. 1991; Vigano and Staudt 1996; Brehm et al. 1997), one of which functions in a cell line-specific manner. This activation domain does not exhibit cell line-restricted expression when linked to the Pit-1 POU domain, implying that the specificity of its function is determined at least in part by the unique configuration assumed by the Oct-3/4 POU domain upon DNA binding (Vigano and Staudt 1996; Brehm et al. 1997). In addition, the ability of a monomer 
of Pit- 1 and the estrogen receptor to synergistically activate the prolactin gene (Crenshaw et al. 1989; Day et al. 1990; Simmons et al. 1990) is dependent on a specific motif in the Pit-1 amino terminus (Holloway et al. 1995). In contrast, on a dimer Pit-1 DNA-binding site, this domain is no longer required for synergy with the estrogen receptor.

\section{Biological roles of POU domain transcription factors}

The expression patterns of POU domain proteins, particularly in the developing nervous system, have suggested that they might function in embryogenesis, both early and during the terminal differentiation of specific cell types, and potential target genes for many of these factors have been predicted based on in vitro cotransfection analysis. However, in many instances, the expression of target genes identified in vitro has been unaffected in animals that are null for either the gene or the functional protein, emphasizing that in vivo characterization of their functions is essential to define their critical biological roles. Therefore, we review the results for all members of this family whose functions have been determined by in vivo analysis.

\section{POU domain proteins in early embryogenesis}

Class V POU domain proteins regulate early events in embryogenesis

Class V POU domain proteins are expressed almost exclusively during the early stages of embryonic development. Xenopus XLPOU-60 (Hinkley et al. 1992; Whitfield et al. 1993), zebrafish pou2 (Takeda et al. 1994; Hauptmann and Gerster 19951, and mammalian Oct-3/4 (Rosner et al. 1990; Schöler et al. 1990) are initially expressed as maternal transcripts. Interestingly, XLPOU60 undergoes a cell-autonomous change in its intracellular distribution from cytoplasmic to nuclear, coincident with the onset of zygotic transcription, suggesting that it may be an important regulator of gene expression in the early embryo (Whitfield et al. 1995). An interspersed RNA family member may be responsible for retaining XLPOU-60 in the cytoplasm /Guttridge and Smith 1995). The dramatic decrease in XLPOU-60 expression during gastrulation correlates with the sequential up-regulation of the class V proteins Oct-25 and Oct91/XLPOU-91 (Frank and Harland 1992; Hinkley et al. 1992), suggesting that these latter proteins are early products of zygotic transcription. Oct-25 and Oct-91/ $X L P O U-91$ expression are subsequently down-regulated during the late gastrula and neurula stages, respectively.

In contrast to $X L P O U-60$, which seems to be present only as a maternal transcript, pou2 and Oct-3/4 are also transcribed zygotically (Rosner et al. 1990; Schöler et al. 1990; Takeda et al. 1994; Hauptmann and Gerster 1995). Down-regulation of pou2 and Oct-3/4 gene expression correlates with the loss of pluripotency, such that, as cells differentiate and lose their capacity to develop along multiple pathways, expression of Oct-3/4 and pou2 is decreased. In the adult, Oct-3/4 is only detectable in the ovaries (Rosner et al. 1990; Schöler et al. 1990). A second mammalian class V gene, Sprm-1, is expressed transiently in male germ cells (Andersen et al. 1993a). Enhancers that regulate distinct portions of the Oct-3/4 expression pattern have been identified (Yeom et al. 1996). During retinoic acid-mediated differentiation of P19 cells, expression of the epiblast-specific enhancer is diminished, suggesting that retinoic acid present in Hensen's node may be partially responsible for down-regulation of Oct-3/4 expression in vivo (Minucci et al. 1996; Yeom et al. 1996). In contrast, pou2 expression in the prospective rhombomeres appears to be positively regulated by retinoic acid (Hauptmann and Gerster 1995).

The expression patterns of the class V POU domain proteins suggest that they may function to regulate genes critical for early cell fate determination and cell proliferation. In zebrafish, overexpression of a truncated version of Pou2 that lacks the homeodomain t-Pou2 prevented embryos from proceeding normally through gastrulation (Takeda et al. 1994). These results suggest that targeted disruption of the murine Oct-3/4 locus may also result in an early embryonic phenotype. Presumably tPou2 inhibits the interaction of the endogenous fulllength Pou2 with specific cofactors or coactivators via squelching. Disruption of the Sprm-1 genomic locus results in decreased fertility, which, although subtle, could be significantly detrimental to genetic fitness (R.V. Pearse II, D.W. Drolet, K.A. Kalla, F. Hooshmand, J.R. Bermingham, Jr., and M.G. Rosenfeld, in prep.).

\section{CEH -18 regulates oogenesis}

The C. elegans POU domain protein CEH-18 may define a novel class of POU proteins. It has a POU-specific domain that is closely related to the mammalian class II POU domain proteins, but its linker and POU homeodomain are significantly more divergent (Greenstein et al. 1994). CEH-18 is expressed in the gonadal sheath cells, which are responsible for signaling the oocyte to maintain meiotic arrest before fertilization; male gonads lack sheath cells and the process of spermatogenesis does not contain a meiotic arrest point. In ceh-18 mutant hermaphrodites, the process of oogenesis is affected, resulting in misshapen and polyploid oocytes, presumably as a result of an inability to maintain cell cycle arrest during development of the oocyte. Whether CEH-18 is a direct regulator of the meiotic arrest signal or is required to regulate processes required for sheath cell terminal differentiation remains to be determined. Mutational analysis indicates that CEH-18 also functions in gonadal migration and epidermal differentiation /Greenstein et al. 1994).

\section{POU domain proteins regulate lineage progression}

Characterization of mutations in the C. elegans unc-86, Drosophila pdm-1 and $p d m-2$, and mammalian Pit-1 genes indicates that their products regulate crucial as- 
pects of lineage progression. Their expression patterns and the phenotype resulting from loss-of-function and/ or gain-of-function mutations suggest that each employs a unique biological mechanism to regulate this process.

\section{Unc-86 couples lineage and identity}

Unc-86 was the first $C$. elegans POU domain protein to be identified (Finney et al. 1988). Mutations in the unc-
86 locus demonstrate that it is required for correct neuroblast lineage progression and terminal differentiation of neurons (Chalfie et al. 1981; Desai et al. 1988). In several neuroblast lineages, Unc-86 is expressed in only one of the two daughter cells resulting from an asymmetric neuroblast division (Finney and Ruvkun 1990 ). In the absence of functional Unc- 86 protein, the daughter cell reiterates the phenotype of the mother cell, and consequently some neurons in the lineage are

\section{A unc-86}
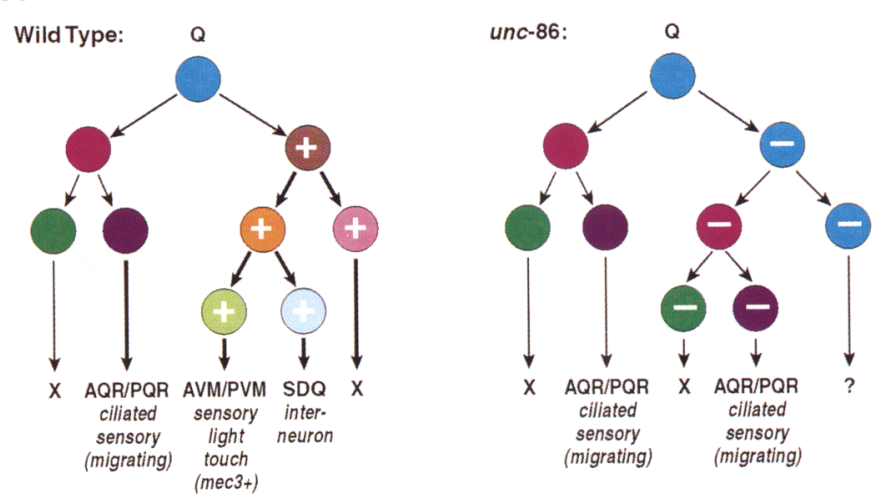

\section{B $p d m-1 / p d m-2$}

Wild Type:
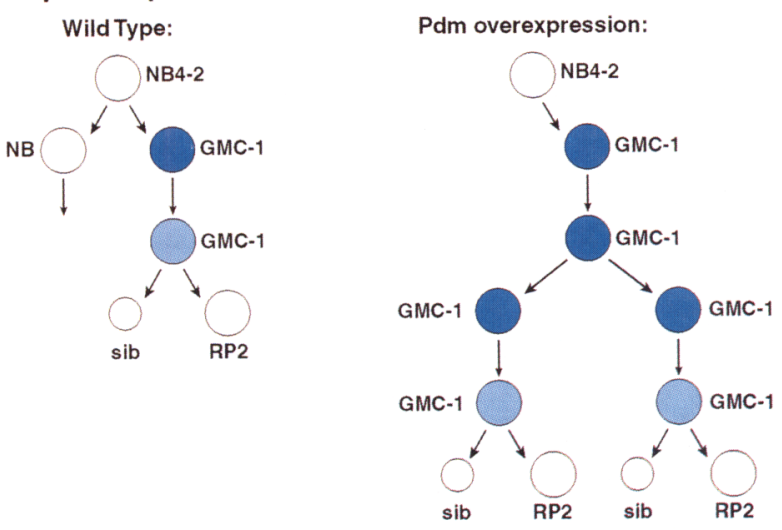

\section{C pit-1}
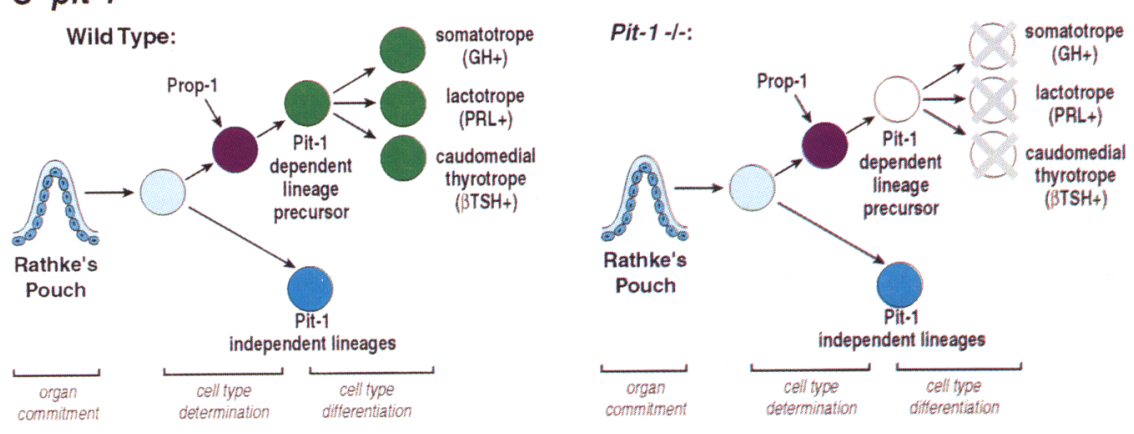

Figure 2. POU domain proteins function in lineage progression. (A) Function of $C$. elegans Unc- 86 in the $\mathrm{Q}$ neuroblast lineage. Expression of Unc-86 protein within this lineage is indicated by a plus sign $(+)$ and distinct cell types within the lineage have each been given a unique color. In the wild type (left), asymmetric division of the $Q$ neuroblast ultimately yields a ciliated sensory neuron (AQR/PQR), a sensory light touch neuron (AVM/PVM), an interneuron (SDQ), and two apoptotic cells (X) In the absence of functional Unc-86 protein $(-)$, the maternal lineage is reiterated (right), resulting in two ciliated sensory neurons at the expense of the AVM sensory touch neuron and the SDQ interneuron. Cells reiterating the parental phenotype are the same color. $(B)$ Function of Drosophila Pdm-1 and Pdm-2 in the NB4-2 neuroblast lineage. In wild-type flies (1eft), Pdm-1 and Pdm-2 are initially expressed at high levels (dark blue) in the ganglion mother cell (GMC-1). A decrease in their expression (light blue) occurs prior to division of the GMC, which generates an RP2 motor neuron and a sibling cell (sib). Overexpression of Pdm-1 or Pdm-2 in the GMC (middle) prevents the normal drop in Pdm expression and consequently division of the GMC produces two additional GMCs. When the level of Pdm protein decreases these then divide to each produce an RP2 motor neuron and the sibling cell. The absence of Pdm-1 and Pdm-2 in the GMC (right) prevents production of RP2 motor neurons. $(C)$ Requirement for Pit-1 in the determination of three cell types in the anterior pituitary gland. Pituitary organ commitment is determined by the formation of Rathke's pouch on mouse embryonic day 8.5-9 and cell type determination commences on embryonic day 10.5. The homeodomain protein Prophet of Pit-1 (Prop-1; purple) is expressed in the cell immediately anterior to Pit-1-positive cells (green) and is essential for the production of the Pit-1 lineage. In wild-type mammals (left), Pit-1 is expressed in the precursor of three lineages and in differentiated somatotropes, lactotropes, and caudomedial thyrotropes where it regulates expression of their respective trophic hormones: growth hormone $(\mathrm{GH})$, prolactin (PRL), and the $\beta$-subunit of thyroid stimulating hormone (TSH $\beta)$. In animals that do not express functional Pit-1 (Pit-1-/-; right), the terminally differentiated somatotropes, lactotropes, and thyrotropes are absent. 
duplicated, whereas others are lost (Finney et al. 1988; Finney and Ruvkun 1990). Thus, Unc- 86 must regulate the transcription of genes whose products change the fate of the Unc- 86 positive cell from that of its mother. This is illustrated for the Q neuroblast lineage in Figure 2A. Similar parental reiteration also occurs in the $\mathrm{V} 5$ and $\mathrm{T}$ lineages of unc-86 mutants (Chalfie et al. 1981).

In a subset of touch receptor neurons that are dependent on the LIM-homeodomain protein Mec-3 for their terminal differentiation (Way and Chalfie 1988), unc-86 is required both for maintenance of the precursor cells and for the initial activation of the mec-3 gene (Xue et al. 1992). Unc-86 and Mec-3 then cooperatively interact to synergistically maintain mec-3 gene expression (Xue et al. 1993; Lichtsteiner and Tjian 1995). Unc-86 is also an important regulator of terminal differentiation events in hermaphrodite-specific neurons (HSNs; Desai et al. 1988). In unc-86 mutants, the HSNs fail to mature morphologically and they neither make correct axonal projections nor express serotonin. Thus, Unc-86 regulates genes required for lineage progression as well as genes required for terminal differentiation of neurons, thereby coupling lineage and cell identity (Finney and Ruvkun 1990).

The complex pattern of asymmetric unc-86 expression is both positively and negatively regulated in a lineagespecific fashion by members of several families of transcription factors, including those containing classic homeodomains, LIM-homeodomains, paired homeodomains, and basic helix-loop-helix (bHLH) family members (Baumeister et al. 1996). Following its initial activation, Unc-86 maintains its own expression through multiple autoregulatory elements embedded in the lineage-specific enhancers of the unc-86 gene.

\section{$P d m-1$ and Pdm-2 are required for generation of RP2 motor neurons}

The genetically linked POU domain genes $p d m-1$ (nubbin, dpou-19) and pdm-2 (miti-mere, dpou-28, doct-2) are most closely related to the mammalian class II factors Oct-1 and Oct-2 (Billin et al. 1991; Dick et al. 1991; Lloyd and Sakonju 1991; Prakash et al. 1992; Cockerill et al. 1993; Ng et al. 1995). Although these factors exhibit gap-like expression patterns in the early embryo and are expressed in the embryonic gut and wing imaginal disc (Affolter et al. 1993; Ng et al. 1995), they have been studied most extensively in the NB4-2 neuroblast lineage. The NB4-2 neuroblast divides to produce a ganglion mother cell (GMC), which subsequently divides to give rise to an RP2 motor neuron and a sibling cell of undetermined fate. Pdm-1 and Pdm-2 are both expressed in the GMC, but neither is expressed in RP2 motor neurons (Yang et al. 1993). Overexpression of Pdm results in reiteration of the GMC, suggesting that $\mathrm{Pdm}$ is required for specification of GMC identity and that down-regulation of Pdm expression prior to the final division of the GMC is a critical component of its differentiation (see Fig. 2B; Yang et al. 1993; Bhat and Schedl 1994; Bhat et al. 1995; Yeo et al. 1995). Both $p d m-1$ and $p d m-2$ are required to achieve a full complement of RP2 motor neurons; deletion of either gene diminishes the number of mature RP2 motor neurons, although disruption of both loci results in a complete absence of RP2 motor neurons without affecting the birth of GMCs (Bhat and Schedl 1994; Bhat et al. 1995; Yeo et al. 1995). Expression of pdm-1 and $p d m-2$ is required only transiently during NB4 lineage progression and its continued expression prevents lineage progression, unlike unc-86, which is expressed in multiple generations of some lineages and is required for expression of target genes in terminally differentiated neurons.

$\mathrm{Pdm}-1$ is also required for the appropriate differentiation and proliferation of the Drosophila wing $(\mathrm{Ng}$ et al. 1995). In the wing primordium, expression of $\mathrm{pdm}-1 /$ nubbin is dependent on the wingless signaling protein ( $\mathrm{Ng}$ et al. 1996). Mutations in the $p d m-1 /$ nubbin locus lead to an almost complete deletion of the adult wing, suggesting a role for Pdm-1 in a previously undefined wing growth control center ( $\mathrm{Ng}$ et al. 1995).

\section{Pit-1 is required for three pituitary lineages}

Pit-1 was cloned based on its ability to interact with elements required for the pituitary-specific expression of the prolactin and growth hormone genes (Bodner et al. 1988; Ingraham et al. 1988). Expression of Pit-1 is limited to the pituitary and, in mice, is observed first in the caudomedial region of the developing anterior pituitary gland on day 13.5 of embryogenesis (Dollé et al. 1990; Simmons et al. 1990). In the mature gland Pit- 1 is expressed in three cell types: thyrotropes, which express thyroid-stimulating hormone (TSH); lactotropes, which express prolactin (PRL); and somatotropes, which express growth hormone (GH) (Ingraham et al. 1988; Simmons et al. 1990). Expression of Pit-1 in heterologous cell lines is sufficient to partially transactivate the pituitaryspecific PRL, GH, and TSH $\beta$ promoters (for review, see Andersen and Rosenfeld 1994). The Snell and Jackson dwarf mice, which have mutations in the Pit-1 locus, have hypoplastic pituitaries and lack the somatotrope, lactotrope, and thyrotrope lineages as determined by the absence of their respective trophic hormones (Fig. 2C; $\mathrm{Li}$ et al. 1990). Point mutations in the human Pit-1 gene result in a similar phenotype; different allelic mutations cause subtle distinctions in their phenotypes (Pfaffle et al. 1992; Radovick et al. 1992; Cohen et al. 1995). Thus, Pit-1 is responsible for the differentiation of specific cell types, regulation of distal target genes, and for the proliferation/survival of cell types within its lineage.

In Snell dwarf mice the initial activation of the Pit-1 gene occurs normally, but expression of the gene is later extinguished, which suggests that Pit-1, like unc-86, is autoregulated (Rhodes et al. 1993). Although there are Pit-1-binding sites in the promoter (Chen et al. 1990; McCormick et al. 1990), a distal enhancer capable of conferring this autoregulation has been identified (Rhodes et al. 1993). Each of the three Pit-1-positive cell types expresses only one trophic hormone, reflecting an additional layer of activating and restricting mechanisms 
within the Pit-1-dependent lineages. Pit-1 function appears to be modulated both by specific coactivators and by interactions with other classes of homeodomain proteins (Seidah et al. 1994; Bach et al. 1995; Zhadanov et al. 1995; Lamonerie et al. 1996; Szeto et al. 1996).

A second genetic dwarf mouse, the Ames mouse, is phenotypically similar to the Snell and Jackson dwarf mice, having a hypoplastic anterior pituitary gland with few, if any, somatotropes, lactotropes, or thyrotropes, and failing to effectively express the Pit-1 gene (Andersen et al. 1995; Gage et al. 1996), indicating that the Ames mutation is epistatic to Pit-1. Recently, a positional cloning approach identified a pituitary-specific paired-like homeodomain protein, Prophet of Pit-1 (Prop1 ), as the candidate for the Ames gene product (Sornson et al. 1996). Prop-1 is capable of binding to sites in an early enhancer of the Pit-1 gene, distinct from the autoregulated late enhancer (DiMattia et al. 1997), and regulating its expression. A point mutation in helix 1 of the Prop-1 homeodomain that impairs its function was identified in the Ames mouse (Sornson et al. 1996). The defect observed in the Ames dwarf appears to reflect a failure of determination of the Pit-1 lineages from perilumenal pituitary cells, suggesting that Prop-1 is required for the asymmetric division that establishes the Pit-1 lineages.

\section{POU domain proteins regulate terminal differentiation events}

\section{Oct-2 regulates terminal differentiation in the} immune system

Expression of Oct-2 at all stages of B cell differentiation and its ability to regulate expression of $B$ cell-restricted genes in vitro suggested that it would be a critical regulator of these events (for review, see Staudt and Lenardo 1991). However, targeted mutagenesis of the Oct-2 locus demonstrated that although vital for the viability of the newborn mouse, Oct-2 is not required for fetal B lymphocyte development (Corcoran et al. 1993). Pre-B cells progress normally through the early and antigen-independent stages of differentiation, including transcription and rearrangement of the immunoglobulin genes, and the transcription rates of genes characteristically expressed in B cells remain unaltered (Corcoran et al. 1993) except for the CD36 and CRISP-3 loci (Konig et al. 1995; Pfisterer et al. 1996). Oct-2 null B cells are defective in their ability to respond to stimulation by polyclonal mitogens and to secrete immunoglobulins (Corcoran et al. 1993; Corcoran and Karvelas 1994). Disruption of the Oct-2 locus in cell lines results in a late phenotype like that seen in the Oct-2 null mouse (Feldhaus et al. 1993).

The ubiquitously expressed Oct-1 and the B cell-specific coactivator OCA-B may compensate for the absence of Oct- 2 and to appropriately regulate the expression of genes required during the early stages of $B$ cell differentiation in Oct-2 null mice. Mice that are null for the $O C A-B$ locus are viable and appear healthy and fertile but have a dramatically weakened immune response
(Kim et al. 1996; Nielsen et al. 1996; Schubart et al. 1996). As in the Oct-2 null mouse, the first stages of B cell differentiation seem to be unaffected, although the progression to mature B cells following antigen stimulation is affected and a severe deficiency in the production of secondary immunoglobulin isotypes is observed (Kim et al. 1996; Nielsen et al. 1996; Schubart et al. 1996). Thus, the events required for differentiation of immunoglobulin-secreting B cells are dependent on both Oct-2 and OCA-B and the additional effects observed in the Oct-2 null mice are probably not related to its interactions with OCA-B.

\section{POU domain factors in development of the nervous system}

A significant number of POU domain proteins are expressed primarily or exclusively in the nervous system. The class III and VI POU domain proteins are expressed broadly during central nervous system (CNS) development, assuming a more restricted pattern as development and differentiation proceed, whereas members of class IV, which are predominantly expressed in the peripheral nervous system (PNS), have a more restricted pattern of expression in the CNS.

\section{Class III POU domain proteins}

Four intronless mammalian class III POU genes, Brn-1, Brn-2, Brn-4, and Tst-1/Oct-6/SCIP have been identified; Tst-1/Oct-6/SCIP is the most divergent member of this class (He et al. 1989; Monuki et al. 1989; Meijer et al. 1990; Suzuki et al. 1990; Hara et al. 1992; LeMoine and Young 1992; Mathis et al. 1992). Class III POU domain genes identified in Drosophila (Johnson and Hirsh 1990), Xenopus (Agarwal and Sato 1991; Baltzinger et al. 1992), and zebrafish (Matsuzaki et al. 1992; Hauptmann and Gerster 1996; Sampath and Stuart 1996; Spaniol et al. 1996) are also expressed predominantly in the CNS.

\section{Brn-2}

The broad expression of Brn-1 and Brn-2 in embryogenesis and antisense RNA experiments, which showed that Brn-2 is potentially required for retinoic acid-induced differentiation of P19 cells (Fujii and Hamada 1993), suggested that they would potentially perform critical functions in early neurogenesis. However, gross histological analysis of Brn-2 null mice indicated that although they do not survive beyond postnatal day 10 , the majority of early neurogenic events are unaffected (Nakai et al. 1995; Schonemann et al. 1995). Deletion of the Brn-2 locus does have a profound effect on development of the endocrine hypothalamus. In Brn-2 null mice, the paraventricular and supraoptic nuclei are markedly hypocellular and do not produce corticotropin-releasing hormone (CRH), oxytocin, or vasopressin (Nakai et al. 1995; Schonemann et al. 1995). However, the expression of other neuropeptide genes expressed in the hypothalamus, including somatostatin, GH-releasing hormone, and thy- 
A Brn-2.0 + Pit-1

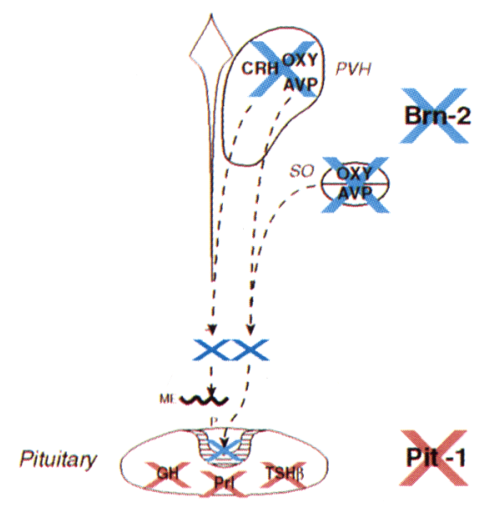

D Brn-3.0

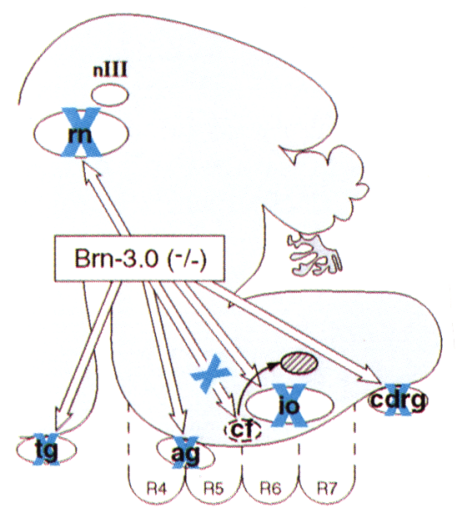

B Tst-1/Oct-6/SCIP

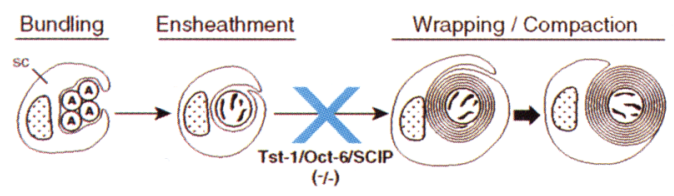

C Oct-2

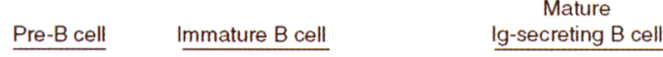

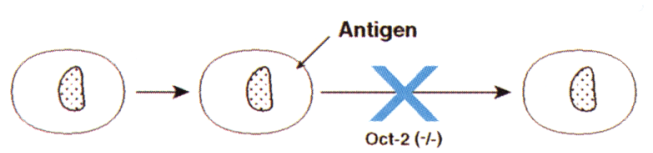

E Brn-3.1

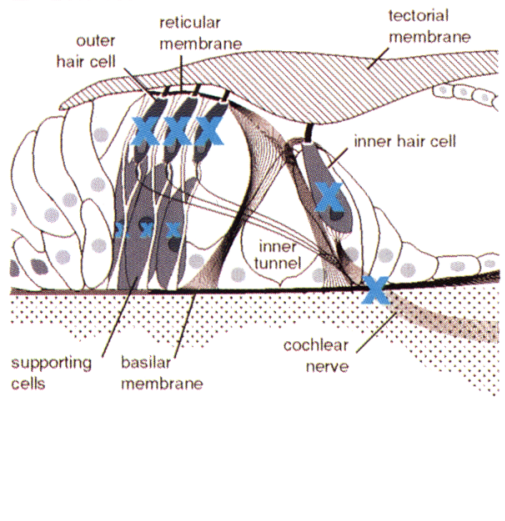

F Brn-3.2

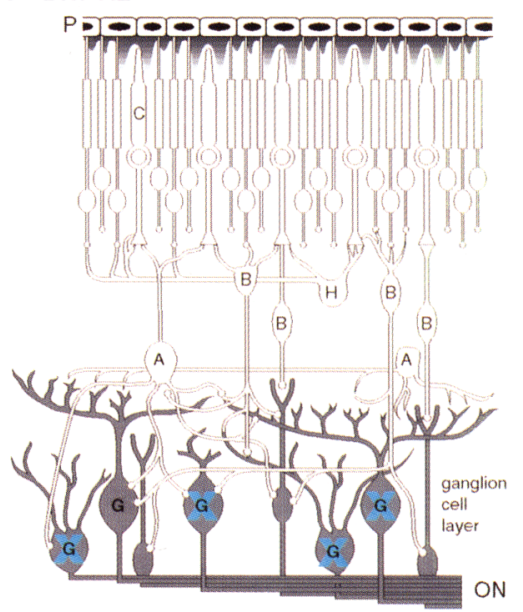

Figure 3. Summary of phenotypes resulting from targeted deletion of POU domain genomic loci. $(A)$ Targeted deletion of the Brn-2 locus and point mutations in the Pit-1 locus. Targeted gene deletion of the Brn-2 locus results in hypocellularity of the paraventricular hypothalamic $(\mathrm{PVH})$ and supraoptic (SO) nuclei, as indicated by the large blue X. Consequently, the neuropeptides corticotropin releasing hormone (CRH), oxytocin (OXY), and arginine vasopressin (AVP) produced by these neurons are absent and these neurons do not make axonal projections to the median eminence (ME) or to the posterior lobe of the pituitary (P). Mutations in the Pit-1 gene results in loss of somatotropes, lactotropes, and thyrotropes and their respective trophic hormones growth hormone (GH), prolactin (Prl\}, and the $\beta$-subunit of thyroid stimulating hormone (TSH $\beta$ ) in the anterior pituitary gland. $(B)$ Targeted disruption of the Tst-1/ Oct-6/SCIP locus affects Schwann cell differentiation. Schwann cells are able to ensheath a single axon; however, the wrapping does not proceed normally, probably causing the marked delay in peripheral myelination observed in Tst-1/Oct-6/SCIP null mice. $(C)$ In the Oct-2 null mouse, B cells proceed normally through the initial steps of differentiation. However, immature B cells are unable to elicit the appropriate response to antigen stimulation, including immunoglobulin secretion. $(D)$ Targeted gene deletion of the Brn3.0/Brn-3a locus causes defects in the CNS, including hypocellularity of the red nucleus (RN) and inferior olive (IO), and the mismigration of the compact formation of the nucleus ambiguus (cf). In addition, defects in the PNS include hypocellularity of the trigeminal ganglion (TG), degeneration of the acoustic ganglion (AG), and hypocellularity and decreased expression of terminal target genes in the upper cervical dorsal root ganglia (cdrg). (E) Disruption of the Brn-3.1/Brn-3c locus affects terminal differentiation of hair cells in the cochlear and vestibular labyrinth. Secondary defects include degeneration of the spiral and vestibular sensory ganglia, as well as an absence or severe distortion of the supporting cells as shown in the schematic diagram of the organ of Corti. (F) Brn-3.2/ $B r n-3 b$ null mice lose $-70 \%$ of the retinal ganglion cells $(\mathrm{G})$, and the optic nerve $(\mathrm{ON})$ is reduced in size, although other cells of the neuroretina are unaffected including the amacrine cells $(A)$, bipolar cells $(B)$, and horizontal cells $(\mathrm{H})$.

rotropin-releasing hormone are relatively unaffected (Schonemann et al. 1995). The presumptive supraoptic and paraventricular hypothalamic neuronal precursors do not survive beyond embryonic day 16 , and consequently they never make axonal projections to the me- dian eminence or to the posterior lobe of the pituitary, resulting in its absence (Fig. 3A; Nakai et al. 1995; Schonemann et al. 1995).

Neurons that produce oxytocin and CRH primarily express Brn-2, whereas the vasopressin-expressing neurons 
express both Brn-2 and Brn-4 protein and Brn-1 transcripts (Schonemann et al. 1995; Malik et al. 1996). Only a small percentage of thryotropin-releasing hormonepositive neurons contain transcripts encoding class III POU domain proteins (Malik et al. 1996). Although Brn-2 appears to be present in these hypothalamic neurons from their inception, it is not required for their initial differentiation, including commitment to neural fate and the onset of their lateral migration from the third ventricle. However, Brn-2 is required for the survival of these neurons and potentially the expression of their neuropeptides. The relatively late phenotype in the Brn-2 null mouse parallels what was observed in the Oct-2 null mouse; although present early, these factors are essential only for the final stages of differentiation in cells in which they are expressed. The inability of Brn-4, which is coexpressed with Brn-2 in at least those neurons expressing vasopressin, to compensate for Brn-2 in terminal differentiation of these neurons may be analogous to the apparent inability of Oct-1 to substitute for Oct-2 in terminal B cell maturation. The discrepancy between Brn-2 antisense experiments, which predicted that Brn-2 would be required for early events in neural development, and the phenotype of the Brn-2 null mouse, could reflect issues of antisense experiments or/ and distinctions between pluripotent P19 cells and neuronal stem cells.

\section{XLPOU-2}

The role of the Xenopus Brn-4 homolog XLPOU-2 in neurogenesis has been addressed via gain-of-function experiments (Witta et al. 1995). XLPOU-2 is initially expressed in Spemann's organizer and then in the involuting mesoderm and the overlying neuroectoderm of gastrula stage embryos. Expression of XLPOU-2 in the neural plate is temporally correlated with neural induction and overexpression and/or misexpression of $X L P O U-2$ in uncommitted ectoderm results in the induction of the neural-specific markers neural cell adhesion molecule (NCAM) and $\beta$-tubulin but not of regionspecific markers (Witta et al. 1995). XLPOU-2 expression is induced by noggin, suggesting that it may regulate early events in neurogenesis. Overexpression of XLPOU2 has also been demonstrated to affect gene expression in Spemann's organizer and suggests that XLPOU-2 may function to regulate pathways responsible for dorsalization of Xenopus embryos (Witta and Sato 1997). In addition to the nervous system, the mammalian Brn-4 homolog is expressed in the outer sheath of whisker roots, the otic vesicle, and limb muscle (Hara et al. 1992; LeMoine and Young 1992; Mathis et al. 1992; Dominov and Miller 1996). However, mutations in the human Brn-4 locus, POU3F4, result in deafness associated with a stapes defect but no other recognized neuronal abnormalities (de Kok et al. 1995), indicating that in humans the potential neurogenic activity exhibited by XLPOU-2 may be subserved by another class III POU domain protein.

\section{Tst-1/Oct-6/SCIP}

Tst-1/Oct-6/SCIP /suppressed cAMP-induced POU) (He et al. 1989; Monuki et al. 1989; Meijer et al. 1990; Suzuki et al. 1990) has been characterized primarily with respect to its expression in oligodendrocyte precursors and in developing Schwann cells, which are responsible for myelination in the CNS and PNS, respectively (Monuki et al. 1990; Collarini et al. 1991; Jensen et al. 1993; Monuki et al. 1993; Scherer et al. 1994), where it has been hypothesized to repress myelination (Monuki et al. 1990, 1993; He et al. 1991). Tst-1/Oct-6/SCIP is also expressed in undifferentiated embryonic stem cells (Meijer et al. 1990; Suzuki et al. 1990), early embryonic ectoderm (Zwart et al. 1996), keratinocytes (He et al. 1989; Faus et al. 1994), and in the developing neuroepithelium and several nuclei in the developing and mature brain (He et al. 1989; Frantz et al. 1994; Alvarez-Bolado et al. 1995; Zwart et al. 1996).

Tst-1/Oct-6/SCIP null mice proceed normally through the early stages of embryogenesis, yet the majority die shortly thereafter (Bermingham et al. 1996; Jaegle et al. 1996). Although central myelination appears to be unaffected in Tst-1/Oct-6/SCIP null mice, peripheral myelination is severely affected a few days after birth. Schwann cells ensheath axons in a 1:1 ratio, but only a small percentage wrap them, indicating a defect in the terminal differentiation of Schwann cells (Fig. 3B). Myelination does not occur precociously, and the expression of several genes that encode myelin structural proteins, predicted to be repressed by Tst-1/Oct-6/SCIP, is unaffected (Bermingham et al. 1996) or reduced (Jaegle et al. 1996). Thus, precocious myelination observed when the Tst-1/Oct-6/SCIP POU domain is expressed under the control of the $P_{0}$ promoter (Weinstein et al. 1995) may be a consequence of the inherent activation function of the Tst-1/Oct-6/SCIP POU domain recently described in vitro (Fyodorov and Deveris 1996). Interestingly, myelination proceeds to completion in Tst-1/Oct6/SCIP null mice that survive several weeks past their birth (Jaegle et al. 1996), consistent with the possibility that these mice retain a slow but progressive ability to complete the wrapping process. Thus, the myelination phenotype of Tst-1/Oct-6/SCIP null mice defines a unique regulatory checkpoint in this process and suggests that Tst-1/Oct-6/SCIP regulates expression of a protein that functions as a "molecular catalyst" for the wrapping process. General neuronal development appears to progress relatively normally in Tst-1/Oct-6/ SCIP null mice, although there were several abnormalities, including disruption of the phrenic nucleus and the apparent mismigration and subsequent death of the neurons of the nucleus of the lateral olfactory tract (Bermingham et al. 1996).

Tst-1/Oct-6/SCIP is capable of synergizing with T antigen to mediate glial-specific transcription of the human papavavirus JC early and late gene expression (Wegner et al. 1993b; Renner et al. 1994). The amino terminus of $\mathrm{T}$ antigen interacts with the Tst-1/Oct-6/SCIP POU domain in a species- and cell type-specific fashion (Sock 
et al. 1996) similarly to what was observed for the interaction of the HSV activator VP16 with Oct-1 (Huang and Herr 1996; Misra et al. 1996). In addition, the Tst-1/Oct6//SCIP POU domain can interact with the high mobility group proteins HMG2 and HMG-I/Y (Leger et al. 1995; Zwilling et al. 1995); its interaction with HMG$\mathrm{I} / \mathrm{Y}$ is required for the activation of the JC early and late genes (Leger et al. 1995). These studies, in conjunction with the observation that the Tst-1/Oct-6/SCIP aminoterminal transactivation domains function in a cell-specific fashion (Monuki et al. 1993) strongly suggest the presence of glial- and neuronal-specific Tst-1/Oct-6/ SCIP coactivators.

\section{Cf1a/ventral veinless/drifter}

Cf1a/drifter/ventral veinless is most closely related to Tst-1/Oct-6/SCIP and is the only Drosophila class III POU identified to date. It was initially cloned by its interaction with an element in the dopa decarboxylase gene required for dopaminergic neuron-specific gene expression (Johnson and Hirsh 1990). During embryogenesis, Cf1a/drifter/ventral veinless is expressed in a pair of midline glia cells, RP3 motor neurons, oenocytes, selected neurons of the ventral nerve cord, in the tracheal placodes and throughout tracheal development, and in wing imaginal discs and wing veins (Anderson et al. 1995; de Celis et al. 1995). Mutations in the Cf1a/ drifter/ventral veinless locus affect growth cone guidance, spacings of the commisures and connections to the CNS, migration of midline glial cells (Anderson et al. 1995; de Celis et al. 1995), and proliferation and differentiation during wing development (de Celis et al. 1995). In addition, severe defects in differentiation of the dorsal and visceral aspects of the tracheal tree as a result of mismigration are observed. The tracheal defect in these flies can be rescued by overexpression of the receptor tyrosine kinase gene breathless; Cfla/drifter/ventral veinless maintains the tracheal expression of the breathless gene in wild-type flies (Anderson et al. 1996).

As with many POU domain proteins, Cf1a/drifter/ ventral veinless expression is autoregulated. Autoregulatory elements embedded within tissue-specific enhancers responsible for its midline glia (DFRE1) and tracheal (DFRE2) expression have been identified (Certel et al. 1996). The DFRE2 element contains an octamer consensus sequence, whereas the DFRE1 element most closely resembles the Oct-1 TAATGARAT element and is similar to the $\mathrm{Cfla} /$ drifter/ventral veinless binding site identified in the dopa decarboxylase promoter, except that the putative core motifs are spaced by 3 nucleotides rather than 0 (Johnson and Hirsh 1990; Certel et al. 1996). The orientation of the two half-sites in the dopa decarboxylase and midline glia DFREl enhancer elements are reversed relative to their orientation in the tracheal DFRE2 octamer element. Thus, like the mammalian class III POU domain protein Brn-2 ( $\mathrm{Li}$ et al. 19931, Cf1a/drifter/ventral veinless is extremely flexible in its ability to recognize diverse DNA response elements and it is likely that the ability of Cfla/drifter/ ventral veinless to interact with tissue-specific coactivators will be site dependent.

In tracheal development, Wingless and Hedgehog signaling molecules appear to regulate $C f 1 a / d r i f t e r / v e n t r a l$ veinless gene expression negatively and positively, respectively (de Celis et al. 1995). Wingless is also proposed to prevent $C f 1 a / d r i f t e r / v e n t r a l$ veinless expression in the developing wing margin, and Notch has been proposed to restrict $C f 1 a / d r i f t e r / v e n t r a l$ veinless expression to the veins. Interestingly, expression of the zebrafish class III POU domain gene, zp50, also overlaps with hedgehog expression (Hauptmann and Gerster 1996). In the ventral diencephalon, zp50 is expressed shortly after the appearance of sonic hedgehog (shh) transcripts, and injection of $s h$ transcripts results in the ectopic zp50 expression. An overlap in shh and mammalian Tst-1/Oct-6/SCIP expression has been observed in the rostral diencephalon (Zwart et al. 1996), raising the possibility that $s h$ may be a regulator of mammalian POU III expression during neural development in mammals.

\section{Class IV POU domain proteins}

The class IV POU domain genes identified in mammals (He et al. 1989; Collum et al. 1992; Lillycrop et al. 1992; Gerrero et al. 1993; Ninkina et al. 1993; Xiang et al. 1993; Turner et al. 1994) are highly related to the unc-86 gene product in C. elegans (Finney et al. 1988). Similar genes are expressed in Drosophila and zebrafish (Sampath and Stuart 1996). As described earlier, the C. elegans protein Unc-86 is a critical regulator of several neuronal lineages and of terminal differentiation. Recently, the functions of the mammalian class IV factors Brn-3.0/Brn-3a, Brn-3.1/Brn-3c, and Brn-3.2/Brn3b, which have overlapping expression patterns in the CNS and PNS and similar DNA-binding preferences, have been examined in mice following targeted disruption of their loci (Fig. 3D-F; Erkman et al. 1996; Gan et al. 1996; McEvilly et al. 1996; Xiang et al. 1996).

\section{Brn-3.0/Brn-3a}

Brn-3.0/Brn-3a is expressed in migrating neural crest cells, the developing and mature sensory ganglia of the PNS, the ganglion cell layer of the retina, and in specific nuclei in the CNS, including the inferior olive, red nucleus, and medial habenula (He et al. 1989; Collum et al. 1992; Gerrero et al. 1993; Turner et al. 1994; Xiang et al. 1995; Fedtsova and Turner 1996; McEvilly et al. 1996). Targeted disruption of the Brn-3.0/Brn-3a genomic locus has a profound effect on the development of the PNS and several nuclei in which Brn-3.0/Brn-3a is expressed, resulting in severe abnormalities in motor coordination and an ineffective swallowing reflex $(\mathrm{McEv}$ illy et al. 1996; Xiang et al. 1996). Neuronal defects are noted in regions of the CNS where Brn-3.0/Brn-3a is uniquely expressed (temporally or spatially) relative to the other class IV POU proteins. Defects in the inferior olive and compact formation of the nucleus ambiguus appear to result from a consequence of neuronal mismi- 
gration, whereas the cell loss in the red nucleus is likely attributable to the subsequent failure of these neurons to survive following their migration (McEvilly et al. 1996; Xiang et al. 1996). No defects were observed in the newborn retina and the relative number of Brn-3.1/Brn-3cand Brn-3.2/Brn-3b-positive neurons was similar to wildtype mice (Xiang et al. 1996). In the PNS the effects of Brn-3.0/Brn-3a gene deletion vary. A severe loss of cells was observed in the acoustic ganglia (McEvilly et al. 1996) and the trigeminal ganglia (McEvilly et al. 1996; Xiang et al. 1996). The loss of Brn-3.1/Brn-3c- and Brn3.2 /Brn-3b-positive neurons in both the trigeminal and dorsal root ganglia (DRG) and the marked hypocellularity in the upper cervical DRG in Brn-3.0/Brn-3a null mice was accompanied by significant decreases in the expression of several neurotrophins and their receptors (McEvilly et al. 1996). The upper cervical ganglia were affected more dramatically than lumbar DRG. This gradient in the severity of these effects is consistent with the hypothesis that the progressive differentiation of Brn-3.0/Brn-3a-positive neurons in the DRG occurs in a rostral to caudal gradient.

\section{Brn-3.1/Brn-3c}

Expression of Brn-3.1/Brn-3c is more restricted than that of other class IV family members. In the sensory ganglia and spinal cord, the level of Brn-3.1/Brn-3c expression is significantly lower than either Brn-3.0/Brn-3a or Brn3.2/Brn-3b (Gerrero et al. 1993; Ninkina et al. 1993; Xiang et al. 1995). However, Brn-3.1/Brn-3c is expressed uniquely and strongly in the hair cells of the inner ear throughout development (Erkman et al. 1996). In contrast to Brn-3.0/Brn-3a null mice, Brn-3.1/Brn-3c null mice survive and seem to be grossly normal at birth. However, they soon develop a balance defect and marked hyperactivity by postnatal day 11 . Examination of the inner ear reveals that neither the cochlear nor the vestibular hair cells acquire their characteristic morphology, stereocilia are absent, and the mice are deaf (Erkman et al. 1996). It is hypothesized that in the absence of functional Brn-3.1/Brn-3c protein the hair cells are unable to differentiate properly and provide the trophic support required for the maintenance of the spiral and vestibular sensory ganglia, which also degenerate in Brn$3.1 / B r n-3 c$ null mice. Thus, in contrast to mutations in the human Brn-4 locus, POU3F4, which have been proposed to result in a stapes defect associated with hearing loss, Brn-3.1/Brn-3c null mice are deaf because of improper differentiation of hair cells and the consequent loss of sensory ganglia.

\section{Brn-3.2/Brn-3b}

The Brn-3.2/Brn-3b expression pattern in the PNS and CNS shows significant spatial overlap with that of Brn3.0/Brn-3a (Lillycrop et al. 1992; Xiang et al. 1993; Turner et al. 1994). However, there are differences in the temporal aspects and relative levels of expression of the two proteins. During embryogenesis, expression of Brn$3.2 /$ Brn-3b protein in the ganglion cell layer of the retina precedes that of Brn-3.0/Brn-3a protein by -2 days (Erkman et al. 1996). The main defect observed in mice harboring a targeted disruption of the $B r n-3.2 / B r n-3 b$ locus is the loss of $\sim 70 \%$ of retinal ganglion cells (Erkman et al. 1996; Gan et al. 1996). In Brn-3.2/Brn-3b null mice, these cells display abnormalities before cellular loss occurs, as Brn-3.0/Brn-3a expression is not observed at its normal time of onset, suggesting that these cells are not engaged in the correct differentiation program and that Brn-3.2/Brn-3b is required from its initial expression for the development of retinal ganglion cells.

Analysis of these mice revealed that each factor performed a critical function affecting the terminal differentiation of cell types in which their expression pattern is temporally or spatially unique, and will permit interpretation of an expanding literature based on DNA-binding and transfection experiments that have been used to infer gene targets (for review, see McEvilly and Rosenfeld 1997).

\section{Summary}

Multidisciplinary approaches have led to the identification of $>30$ families of DNA-binding proteins, each of which contains members that have arisen following gene duplication and rearrangement events to serve the progressively increased regulatory requirements of more complex metazoans. Examination of the POU domain gene family has provided an opportunity to explore the combination of shared features and functions, as well as the diversity of actions that are assumed by different members within a gene family of transcription factors. An identifying feature of POU domain proteins is their bipartite DNA-binding domain, which can be conceptualized as an intramolecular dimer consisting of two distinct, linked DNA-binding motifs, which permits the flexibility of binding to sites exhibiting different spacing and orientation of core DNA motifs, analogous to that of the heterodimeric binding pairs in the nuclear receptor and bHLH gene families. The ability of the DNA site to allosterically modulate the specificity of POU domain coactivator interactions and the observation that POU domain proteins utilize distinct coactivators, depending upon whether they bind DNA as a monomer or dimer, provides a molecular basis by which specific POU domain proteins can regulate distinct sets of genes with temporal and spatial specificity. The effects of POU domain phosphorylation on DNA binding, the requirement of POU domain proteins in specific gene activation by nuclear receptor ligands, and a specific example of a cellautonomous cytoplasmic to nuclear translocation indicate that POU domain proteins exploit multiple regulatory strategies to execute programs of gene activation.

Most POU domain factors exhibit spatially and temporally restricted expression patterns during development, and these patterns are consistent with the possibility that specific signal transduction pathways are required for their activation. Retinoic acid and the bone morphogenetic protein, hedgehog, and Wnt signaling pathways have been suggested to influence POU domain 
gene expression either directly or indirectly. Many POU domain factors exhibit autoregulation, providing a type of memory of determination, utilizing distinct mechanisms for their initial activation versus maintenance of their expression. In the case of Pit-1, distinct early and late enhancers have been identified, the latter being autoregulated and sufficient for maintenance of expression.

Consistent with the ontogeny of their expression, several POU domain proteins have been shown to be key regulators of early embryonic development, cell replication, and lineage determination, whereas most exert much later developmental roles. The distinct, yet overlapping expression patterns of class III and IV POU domain genes in the nervous system suggested that they would fulfill roles both early and late in neuronal determination and development. However, the consequence of targeted deletion of individual POU domain loci has been manifest most often by disruption of terminal neuronal differentiation events, including migration, axonal guidance, expression of a series of distal target genes such as neurotrophins and their receptors, and in many cases neuronal survival. Detailed analysis has revealed that altered patterns of gene expression often commence far before detectable morphological changes. These studies reveal that POU domain target genes required for neuronal differentiation and survival include neurotrophic factors and their receptors, other transcription factors, and potentially members of the immunoglobulin superfamily. The relatively restricted phenoptype observed in some of the null mice and the apparent absence of morphological changes early in neural development suggest that the remaining POU domain proteins may be capable of performing compensatory functions in the absence of a closely related family member, a testable hypothesis. Overall, members of the POU domain family appear to function relatively late in developmental transcriptional cascades, regulating events required for terminal differentiation. In addition to their biological roles in gene regulation, POU domain factors appear to have been coopted as a component of a regulatory strategy by which various DNA viruses achieve cell-type specific expression in skin, sensory ganglia, and myelinating glia.

\section{Acknowledgments}

Because of space limitations, we apologize that we were unable to cite many colleagues who have made valuable contributions to the understanding of the biochemcial mechanisms by which POU domain proteins function. We acknowledge members of the Rosenfeld laboratory for helpful discussions and criticisms in the preparation of this manuscript, especially Drs. Linda Erkman, Bogi Andersen, John Bermingham, Jr., and Robert McEvilly; and the assistance of Beth Stawiarski and Peggy Myer in preparation of the manuscript and figures, respectively. A.K.R. is a recipient of a National Research Service Award from the National Institutes of Health. M.G.R. is an investigator with the Howard Hughes Medical Institute.

\section{References}

Affolter, M., U. Walldorf., U. Kloter, A.F. Schier, and W.J. Ge- hring. 1993. Regional repression of a Drosophila POU box gene in the endoderm involves inductive interactions between germ layers. Development 117: 1199-1210.

Agarwal, V.R. and S.M. Sato. 1991. XLPOU 1 and XLPOU 2, two novel POU domain genes expressed in the dorsoanterior region of Xenopus embryos. Dev. Biol. 147: 363-373.

Alvarez-Bolado, G., M.G. Rosenfeld, and L.W. Swanson. 1995. Model of forebrain regionalization based on spatiotemporal patterns of POU-III homeobox gene expression, birthdates, and morphological features. J. Comp. Neurol. 355: 237-295.

Andersen, B. and M.G. Rosenfeld. 1994. Pit-1 determines cell types during development of the anterior pituitary gland: A model for transcriptional regulation of cell phenotypes in mammalian organogenesis. I. Biol. Chem. 269: 2933529338.

Andersen, B., R.V. Pearse, P.N. Schlegel, Z. Cichon, M.D. Schonemann, C.W. Bardin, and M.G. Rosenfeld. 1993a. Sperm 1: A POU-domain gene transiently expressed immediately before meiosis I in the male germ cell. Proc. Natl. Acad. Sci. 90: 11084-11088.

Andersen, B., M.D. Schonemann, S.E. Flynn, R.V. Pearse II, H. Singh, and M.G. Rosenfeld. 1993b. Skn-1a and Skn-1i: Two functionally distinct Oct-2-related factors expressed in epidermis. Science 260: 78-82.

Andersen, B., M.D. Schonemann, R.V. Pearse II, K. Jenne, J. Sugarman, and M.G. Rosenfeld. 1993c. Brn-5 is a divergent POU domain factor highly expressed in layer IV of the neocortex. J. Biol. Chem. 268: 23390-23398.

Andersen, B., R.V. Pearse II, K. Jenne, M. Sornson, S-C. Lin, A. Bartke, and M.G. Rosenfeld. 1995. The Ames dwarf gene is required for Pit-1 gene activation. Dev. Biol. 172: 495-503.

Anderson, M.G., G.L. Perkins, P. Chittick, R.J. Shrigley, and W.A. Johnson. 1995. drifter, a Drosophila POU-domain transcription factor, is required for correct differentiation and migration of tracheal cells and midline glia. Genes \& Dev. 9: $123-137$.

Anderson, M.G., S.J. Certel, K. Certel, T. Lee, D.J. Montell, and W.A. Johnson. 1996. Function of the Drosophila POU domain transcription factor Drifter as an upstream regulator of Breathless receptor tyrosine kinase expression in developing trachea. Development 122: 4169-4178.

Assa-Munt, N., R.J. Mortishire-Smith, R. Aurora, W. Herr, and P.E. Wright. 1993. The solution structure of the Oct-1 POUspecific domain reveals a striking similarity to the bacteriophage lambda repressor DNA-binding domain. Cell 73: 193 205.

Bach, I., S.J. Rhodes, R.V. Pearse II, T. Heinzel, B. Gloss, K.M. Scully, P.E. Sawchenko, and M.G. Rosenfeld. 1995. P-Lim, a LIM homeodomain factor, is expressed during pituitary organ and cell commitment and synergizes with Pit-1. Proc. Natl. Acad. Sci. 92: 2720-2724.

Baltzinger, M., E. Payen, and P. Remy. 1992. Nucleotide sequence of XLPOU3 cDNA, a member of the POU domain gene family expressed in Xenopus laevis embryos. Nucleic Acids Res. 20: 1993.

Baumeister, R., Y. Liu, and G. Ruvkun. 1996. Lineage-specific regulators couple cell lineage asymmetry to the transcription of the Caenorhabditis elegans POU gene unc-86 during neurogenesis. Genes \& Dev. 10: 1395-1410.

Bermingham, J.R., Jr., S.S. Scherer, S. O'Connell, E. Arroyo, K.A. Kalla, F.L. Powell, and M.G. Rosenfeld. 1996. Tst-1/Oct-6/ SCIP regulates a unique step in peripheral myelination and is required for normal respiration. Genes \& Dev. 10: 17511762 .

Bhat, K.M. and P. Schedl. 1994. The Drosophila miti-mere gene, a member of the POU family, is required for the specification 
of the RP2/sibling lineage during neurogenesis. Development 120: 1483-1501.

Bhat, K.M., S.J. Poole, and P. Schedl. 1995. The miti-mere and pdml genes collaborate during specification of the RP2/sib lineage in Drosophila neurogenesis. Mol. Cell. Biol. 15: 4052-4063.

Billin, A.N., K.A. Cockerill, and S.J. Poole. 1991. Isolation of a family of Drosophila POU domain genes expressed in early development. Mech. Dev. 34: 75-84.

Bodner, M., J.L. Castrillo, L.E. Theill, T. Deerinck, M. Ellisman, and M. Karin. 1988. The pituitary-specific transcription factor GHF-1 is a homeobox-containing protein. Cell 55: 505518.

Botfield, M.C., A. Jancso, and M.A. Weiss. 1992. Biochemical characterization of the Oct-2 POU domain with implication for bipartite DNA recognition. Biochemistry 31: 5841-5848.

Brehm, A., K. Ohbo, and H. Scholer. 1997. The carboxy-terminal transactivation domain of Oct-4 acquires cell specificity through the POU domain. Mol. Cell. Biol. 17: 154-162.

Bulleit, R.F., H. Cui, J. Wang, and X. Lin. 1994. NMDA receptor activation in differentiating cerebellar cell cultures regulates the expression of a new POU gene, Cns-1. I. Neurosci. 14: $1584-1595$.

Burglin, T.R., M. Finney, A. Coulson, and G. Ruvkun. 1989. Caenorhabditis elegans has scores of homoeobox-containing genes. Nature 341: 239-243.

Caelles, C., H. Hennemann, and M. Karin. 1995. M-phase-specific phosphorylation of the POU transcription factor GHF-1 bya cell cycle-regulated protein kinase inhibits DNA binding. Mol. Cell. Biol. 15: 6694-6701.

Cepek, K.L., D.I. Chasman, and P.A. Sharp. 1996. Sequencespecific DNA binding of the B-cell-specific coactivator OCAB. Genes \& Dev. 10: 2079-2088.

Certel, K., M.G. Anderson, R.J. Shrigley, and W.A. Johnson. 1996. Distinct variant DNA-binding sites determine cellspecific autoregulated expression of the Drosophila POU domain transcription factor drifter in midline glia or trachea. Mol. Cell. Biol. 16: 1813-1823.

Chalfie, M., H.R. Horvitz, and J.E. Sulston. 1981. Mutations that lead to reiterations in the cell lineages of $\mathrm{C}$. elegans. Cell 24: 59-69.

Char, B.R., J.R. Bell, J. Dovala, J.A. Coffman, M.G. Harrington, J.C. Becerra, E.H. Davidson, F.J. Calzone, and R. Maxson. 1993. SpOct, a gene encoding the major octamer-binding protein in sea urchin embryos: Expression profile, evolutionary relationships, and DNA binding of expressed protein. Dev. Biol. 158: 350-363.

Chen, R.P., H.A. Ingraham, M.N. Treacy, V.R. Albert, L. Wilson, and M.G. Rosenfeld. 1990. Autoregulation of pit-1 gene expression mediated by two cis-active promoter elements. Nature 346: 583-586.

Cleary, M.A. and W. Herr. 1995. Mechanisms for flexibility in DNA sequence recognition and VP16-induced complex formation by the Oct-1 POU domain. Mol. Cell. Biol. 15: 20902100 .

Clerc, R.G., L.M. Corcoran, J.H. LeBowitz, D. Baltimore, and P.A. Sharp. 1988. The B-cell-specific Oct-2 protein contains POU box- and homeo box-type domains. Genes \& Dev. 2: $1570-1581$.

Cockerill, K.A., A.N. Billin, and S.J. Poole. 1993. Regulation of expression domains and effects of ectopic expression reveal gap gene-like properties of the linked pdm genes of Drosophila. Mech. Dev. 41: 139-153.

Cohen, L.E., F.E. Wondisford, A. Salvatoni, M. Maghnie, F. Brucker-Davis, B.D. Weintraub, and S. Radovick. 1995. A "hot spot" in the Pit-1 gene responsible for combined pitu- itary hormone deficiency: Clinical and molecular correlates. J. Clin. Endo. Metab. 80: 679-684.

Collarini, E.J., N. Pringle, H. Mudhar, G. Stevens, R. Kuhn, E.S. Monuki, G. Lemke, and W.D. Richardson. 1991. Growth factors and transcription factors in oligodendrocyte development. J. Cell Sci. 15: 117-123.

Collum, R.G., P.E. Fisher, M. Datta, S. Mellis, C. Thiele, K. Huebner, C.M. Croce, M.A. Israel, T. Theil, T. Moroy et al. 1992. A novel POU homeodomain gene specifically expressed in cells of the developing mammalian nervous system. Nucleic Acids Res. 20: 4919-4925.

Corcoran, L.M. and M. Karvelas. 1994. Oct-2 is required early in $T$ cell-independent $B$ cell activation for G1 progression and for proliferation. Immunity 1: 635-645.

Corcoran, L.M., M. Karvelas, G.J. Nossal, Z.S. Ye, T. Jacks, and D. Baltimore. 1993. Oct-2, although not required for early B-cell development, is critical for later B-cell maturation and for postnatal survival. Genes \& Dev. 7: 570-582.

Cox, M., P.J. van Tilborg, W. de Laat, R. Boelens, H.C. van Leeuwen, P.C. van der Vliet, and R. Kaptein. 1995. Solution structure of the Oct-1 POU homeodomain determined by NMR and restrained molecular dynamics. I. Biomol. NMR 6: 23-32.

Crenshaw, E.B., III, K. Kalla, D.M. Simmons, L.W. Swanson, and M.G. Rosenfeld. 1989. Cell-specific expression of the prolactin gene in transgenic mice is controlled by synergistic interactions between promoter and enhancer elements. Genes \& Dev. 3: 959-972.

Dawson, S.J., Y.Z. Liu, B. Rodel, T. Moroy, and D.S. Latchman. 1996. The ability of POU family transcription factors to activate or repress gene expression is dependent on the spacing and context of their specific response elements. Biochemical I. 314: 439-443.

Day, R.N., S. Koike, M. Sakai, M. Muramatsu, and R.A. Maurer. 1990. Both Pit-1 and the estrogen receptor are required for estrogen responsiveness of the rat prolactin gene. Mol. Endocrin. 4: 1964-1971.

de Celis, J.F., M. Llimargas, and J. Casanova. 1995. Ventral veinless, the gene encoding the Cfla transcription factor, links positional information and cell differentiation during embryonic and imaginal development in Drosophila melanogaster. Development 121: 3405-3416.

Dekker, N., M. Cox, R. Boelens, C.P. Verrijzer, P.C. van der Vliet, and R. Kaptein. 1993. Solution structure of the POUspecific DNA-binding domain of Oct-1. Nature 362: 852855.

de Kok, Y.J., S.M. van der Maarel, M. Bitner-Glindzicz, I. Huber, A.P. Monaco, S. Malcolm, M.E. Pembrey, H.H. Ropers, and F.P. Cremers. 1995. Association between X-linked mixed deafness and mutations in the POU domain gene POU3F4. Science 267: 685-658.

Desai, C., G. Garriga, S.L. McIntire, and H.R. Horvitz. 1988. A genetic pathway for the development of the Caenorhabditis elegans HSN motor neurons. Nature 336: 638-646.

Dick, T., X.H. Yang, S.L. Yeo, and W. Chia. 1991. Two closely linked Drosophila POU domain genes are expressed in neuroblasts and sensory elements. Proc. Natl. Acad. Sci. 88: 7645-7649.

DiMattia, G.E., S.J. Rhodes, A. Krones, C. Carrière, S. O'Connell, K. Kalla, C. Arias, P. Sawchenko, and M.G. Rosenfeld. 1997. The Pit-1 gene is regulated by distinct early and late pituitaryspecific enhancers. Dev. Biol. 182: 180-190.

Dollé, P., J.L. Castrillo, L.E. Theill, T. Deerinck, M. Ellisman, and M. Karin. 1990. Expression of GHF-1 protein in mouse pituitaries correlates both temporally and spatially with the onset of growth hormone gene activity. Cell 60: 809-820. 
Dominov, J.A. and J.B. Miller. 1996. POU homeodomain genes and myogenesis. Dev. Genet. 19: 108-118.

Erkman, L., R.J. McEvilly, L. Luo, A.K. Ryan, F. Hooshmand, S.M. O'Connell, D.H. Rapaport, A.F. Ryan, and M.G. Rosenfeld. 1996. Role of transcription factors Brn-3.1 and Brn-3.2 in auditory and visual system development. Nature 381: 603-606.

Faus, I., H.J. Hsu, and E. Fuchs. 1994. Oct-6: A regulator of keratinocyte gene expression in stratified squamous epithelia. Mol. Cell. Biol. 14: 3263-3275.

Fedtsova, N.G. and E.E. Turner, 1995. Brn-3.0 expression identifies early post-mitotic CNS neurons and sensory neural precursors. Mech. Dev. 53: 291-304.

Feldhaus, A.L., C.A. Klug, K.L. Arvin, and H. Singh. 1993. Targeted disruption of the Oct- 2 locus in a B cell provides genetic evidence for two distinct cell type-specific pathways of octamer element-mediated gene activation. EMBO $I$. 12: 2763-2772.

Finney, M. and G. Ruvkun. 1990. The unc-86 gene product couples cell lineage and cell identity in C. elegans. Cell 63: $895-905$.

Finney, M., G. Ruvkun, and H.R. Horvitz. 1988. The C. elegans cell lineage and differentiation gene unc- 86 encodes a protein with a homeodomain and extended similarity to transcription factors. Cell 55: 757-769.

Frank, D. and R.M. Harland. 1992. Localized expression of a Xenopus POU gene depends on cell-autonomous transcriptional activation and induction-dependent inactivation. $\mathrm{De}$ velopment 115: 439-448.

Frantz, G.D., A.P. Bohner, R.M. Akers, and S.K. McConnell. 1994. Regulation of the POU domain gene SCIP during cerebral cortical development. I. Neurosci. 14: 472-485.

Fujii, H. and H. Hamada. 1993. A CNS-specific POU transcription factor, Brn-2, is required for establishing mammalian neural cell lineages. Neuron 11: 1197-1206.

Fyodorov, D. and E. Deneris. 1996. The POU domain of SCIP/ Tst-1/Oct- 6 is sufficient for activation of any acetylcholine receptor promoter. Mol. Cell. Biol. 16: 5004-5014.

Gage, P.I., M.L. Roller, T.L. Saunders, L.M. Scarlett, and S.A. Camper. 1996. Anterior pituitary cells defective in the cellautonomous factor, $\mathrm{df}$, undergo cell lineage specification but not expansion. Development 122: 151-160.

Gan, L., M. Ziang, L. Zhou, D.S. Wagner, W.H. Klein, and J. Nathans. 1996. POU domain factor Brn-3b is required for the development of a large set of retinal ganglion cells. Proc. Natl. Acad. Sci. 93: 3920-3925.

Gerrero, M.R., R.J. McEvilly, E. Turner, C.R. Lin, S. O'Connell, K.J. Jenne, M.V. Hobbs, and M.G. Rosenfeld. 1993. Brn-3.0: A POU-domain protein expressed in the sensory, immune, and endocrine systems that functions on elements distinct from known octamer motifs. Proc. Natl. Acad. Sci. 90: 1084110845 .

Gerster, T. and R.G. Roeder. 1988. A herpesvirus trans-activating protein interacts with transcription factor OTF-1 and other cellular proteins. Proc. Nat1. Acad. Sci. 85: 6347-6351.

Greenstein, D., S. Hird, R.H. Plasterk, Y. Andachi, Y. Kohara, B. Wang, M. Finney, and G. Ruvkun. 1994. Targeted mutations in the Caenorhabditis elegans POU homeo box gene ceh-18 cause defects in oocyte cell cycle arrest, gonad migration, and epidermal differentiation. Genes \& Dev. 8: 1935-1948.

Gruber, C.A., J.M. Rhee, A. Gleiberman, and E.E. Turner. 1997. POU-domain factors of the Brn-3 class recognize functional DNA elements which are distinctive, symmetrical, and highly conserved in evolution. Mol. Cell. Biol. 17: 23912400.

Gstaiger, M., L. Knoepfel, O. Georgiev, W. Schaffner, and C.M.
Hovens. 1995. A B-cell coactivator of octamer-binding transcription factors. Nature 373: 360-362.

Gstaiger, M., O. Georgiev, H. van Leeuwen, P. van der Vliet, and W. Schaffner. 1996. The B cell coactivator Bob1 shows DNA sequence-dependent complex formation with Oct-1/Oct-2 factors, leading to differential promoter activation. EMBO $\mathrm{I}$. 15: 2781-2790.

Guttridge, K.L. and L.D. Smith. 1995. Xenopus interspersed RNA families, Ocr and XR, bind DNA-binding proteins. $Z y$ gote 3: 111-122.

Hara, Y., A.C. Rovescalli, Y. Kim, and M. Nirenberg. 1992. Structure and evolution of four POU domain genes expressed in mouse brain. Proc. Natl. Acad. Sci. 89: 3280-3284.

Hauptmann, G. and T. Gerster. 1995. Pou-2-a zebrafish gene active during cleavage stages and in the early hindbrain. Mech. Dev. 51: 127-138.

1996. Complex expression of the $z p-50$ pou gene in the embryonic zebrafish brain is altered by overexpression of sonic hedgehog. Development 122: 1769-1780.

He, X., M.N. Treacy, D.M. Simmons, H.A. Ingraham, L.W. Swanson, and M.G. Rosenfeld. 1989. Expression of a large family of POU-domain regulatory genes in mammalian brain development. Nature 340: 35-41.

He, X., R. Gerrero, D.M. Simmons, R.E. Park, C.J. Lin, L.W Swanson, and M.G. Rosenfeld. 1991. Tst-1, a member of the POU domain gene family, binds the promoter of the gene encoding the cell surface adhesion molecule P0. Mol. Cell. Biol. 11: 1739-1744.

Herr, W. and M.A. Cleary. 1995. The POU domain: Versatility in transcriptional regulation by a flexible two-in-one DNAbinding domain. Genes \& Dev. 9: 1679-1693.

Herr, W., R.A. Sturm, R.G. Clerc, L.M. Corcoran, D. Baltimore, P.A. Sharp, H.A. Ingraham, M.G. Rosenfeld, M. Finney, G. Ruvkun, and H.R. Horvitz. 1988. The POU domain: A large conserved region in the mammalian pit-1, oct-1, oct-2, and Caenorhabditis elegans unc-86 gene products. Genes \& Dev. 2: 1513-1516.

Hinkley, C.S., J.F. Martin, D. Leibham, and M. Perry. 1992. Sequential expression of multiple POU proteins during amphibian early development. Mol. Cell. Biol. 12: 638-649.

Holloway, J.M., D.P. Szeto, K.M. Scully, C.K. Glass, and M.G. Rosenfeld. 1995. Pit-1 binding to specific DNA sites as a monomer or dimer determines gene-specific use of a tyrosine-dependent synergy domain. Genes \& Dev. 9: 1992-2006.

Huang, C.C. and W. Herr. 1996. Differential control of transcription by homologous homeodomain coregulators. Mol. Cell. Biol. 16: 2967-2976.

Imagawa, M., A. Miyamoto, M. Shirakawa, H. Hamada, and M. Muramatsu. 1991. Stringent integrity requirements for both trans-activation and DNA-binding in a trans-activator, Oct3. Nucleic Acids Res. 19: 4503-4508.

Ingraham, H.A., R.P. Chen, H.J. Mangalam, H.P. Elsholtz, S.E. Flynn, C.R. Lin, D.M. Simmons, L. Swanson, and M.G. Rosenfeld. 1988. A tissue-specific transcription factor containing a homeodomain specifies a pituitary phenotype. Cell 55: 519-529.

Ingraham, H.A., S.E. Flynn, J.W. Voss, V.R. Albert, M.S. Kapiloff, L. Wilson, and M.G. Rosenfeld. 1990. The POU-specific domain of Pit-1 is essential for sequence-specific, high affinity DNA binding and DNA-dependent Pit-1-Pit-1 interactions. Cell 61: 1021-1033.

Jacobson, E.M., P. Li, A. Leon-del-Rio, M.G. Rosenfeld, and A. Aggarwal. 1997. Structure of Pit-1 POU domain bound to DNA as a dimer: Unexpected arrangement and flexibility. Genes \& Dev. 11: 198-212. 
Jaegle, M., W. Mandemakers, L. Broos, R. Zwart, A. Karis, P. Visser, F. Grosveld, and D. Meijer. 1996. The POU factor Oct-6 and Schwann cell differentiation. Science 273: 507510.

Jensen, N.A., G.M. Smith, J.S. Garvey, H.D. Shine, and L. Hood. 1993. Cyclic AMP has a differentiative effect on an immortalized oligodendrocyte cell line. I. Neurosci. Res. 35: 288296.

Johansen, T., U. Moens, T. Holm, A. Fjose, and S. Krauss. 1993. Zebrafish pou[c]: A divergent POU family gene ubiquitously expressed during embryogenesis. Nucleic Acids Res. 21: 475-483.

Johnson, W.A. and J. Hirsh. 1990. Binding of a Drosophila POUdomain protein to a sequence element regulating gene expression in specific dopaminergic neurons. Nature 343: 467 470.

Kapiloff, M.S., Y. Farkash, M. Wegner, and M.G Rosenfeld. 1991. Variable effects of phosphorylation of Pit-1 dictated by the DNA response elements. Science 253: 786-789.

Kim, U., X.F. Qin, S. Gong, S. Stevens, Y. Luo, M. Nussenzweig, and R.G. Roeder. 1996. The B-cell-specific transcription coactivator OCA-B/OBF-1/Bob-1 is essential for normal production of immunoglobulin isotypes. Nature 383: 542-547.

Klemm, J.D. and C.O. Pabo. 1996. Oct-1 POU domain-DNA interactions: Cooperative binding of isolated subdomains and effects of covalent linkage. Genes \& Dev, 10: 27-36.

Klemm, I.D., M.A. Rould, R. Aurora, W. Herr. and C.O. Pabo. 1994. Crystal structure of the Oct-1 POU domain bound to an octamer site: DNA recognition with tethered DNA-binding modules. Cell 77: 21-32.

Ko, H.S., P. Fast, W. McBride, and L.M. Staudt. 1988. A human protein specific for the immunoglobulin octamer DNA motif contains a functional homeobox domain. Cell 55: 135144.

Konig, H., P. Pfisterer, L.M. Corcoran, and T. Wirth. 1995. Identification of CD36 as the first gene dependent on the B-cell differentiation factor Oct-2. Genes \& Dev. 9: 1598-1607.

Koyasu, S., R.E. Hussey, L.K. Clayton, A. Lerner, R. Pedersen, P. Delany-Heiken, F. Chau, and E.L. Reinherz. 1994. Targeted disruption within the CD3 zeta/eta/phi/Oct-1 locus in mouse. EMBO J. 13: 784-797.

Kristie, T.M. and P.A. Sharp. 1990. Interactions of the Oct-1 POU subdomains with specific DNA sequences and with the HSV $\alpha$-trans-activator protein. Genes \& Dev. 4: 2383-2396.

Kristie, T.M., J.H. LeBowitz, and P.A. Sharp. 1989. The octamerbinding proteins form multi-protein-DNA complexes with the HSV alpha TIF regulatory protein. $E M B O \quad I$. 8: 4229-4238.

Lamonerie, T., J.J. Tremblay, C. Lanctot, M. Therrien, Y. Gauthier, and J. Drouin. 1996. Ptxl, a bicoid-related homeo box transcription factor involved in transcription of the proopiomelanocortin gene. Genes \& Dev. 10: 1284-1295.

Leger, H., E. Sock, K. Renner, F. Grummt, and M. Wegner. 1995. Functional interaction between the POU domain protein Tst-1/Oct-6 and the high-mobility-group protein HMG-I/Y. Mol. Cell. Biol, 15: 3738-3747.

LeMoine, C. and W.D. Young III. 1992. RHS2, a POU domaincontaining gene, and its expression in developing and adult rat. Proc. Natl. Acad. Sci. 89: 3285-3289.

Li, P., X. He, M.R. Gerrero, M. Mok, A. Aggarwal, and M.G. Rosenfeld. 1993. Spacing and orientation of bipartite DNAbinding motifs as potential functional determinants for POU domain factors. Genes \& Dev. 7: 2483-2496.

Li, S., E.B. Crenshaw III, E.J. Rawson, D.M. Simmons, L.W. Swanson, and M.G. Rosenfeld. 1990. Dwarf locus mutants lacking three pituitary cell types result from mutations in the POU-domain gene pit-1. Nature 347: 528-533.

Lichtsteiner, S. and R. Tjian. 1995. Synergistic activation of transcription by UNC- 86 and MEC-3 in C. elegans embryo extracts. $E M B O T$. 14: 3937-3945.

Lillycrop, K.A., V.S. Budrahan, N.D. Lakin, G. Terrenghi, J.N. Wood, J.M. Polak, and D.S. Latchman. 1992. A novel POU family transcription factor is closely related to Brn-3 but has a distinct expression pattern in neuronal cells. Nucleic Acids Res. 20: 5093-5096.

Lloyd, A. and S. Sakonju. 1991. Characterization of two Drosophila POU domain genes, related to oct- 1 and oct-2, and the regulation of their expression patterns. Mech. Dev. 36: $87-102$.

Luo, Y. and R.G. Roeder. 1995. Cloning, functional characterization, and mechanism of action of the B-cell-specific transcriptional coactivator OCA-B. Mol. Cell. Biol. 15: 41154124.

Malik, K.F., J. Kim, A.L. Hartman, P. Kim, and W.S. Young III. 1996. Binding preferences of the POU domain protein Brain4: Implications for autoregulation. Brain Res. Mol. Brain Res. 38: 209-221.

Mathis, J.M., D.M. Simmons, X. He, L.W. Swanson, and M.G. Rosenfeld. 1992. Brain 4: A novel mammalian POU domain transcription factor exhibiting restricted brain-specific expression. EMBO 1. 11: 2551-2561.

Matsuzaki, T., H. Amanuma, and H. Takeda. 1992. A POU domain gene of zebrafish, ZFPOU1, specifically expressed in the developing neural tissues. Biochem. Biophys. Res. Comm. 187: 1446-1453.

McCormick, A., H. Brady, L.E. Theill, and M. Karin. 1990. Regulation of the pituitary-specific homeobox gene GHF1 by cellautonomous and environmental cues. Nature 345: 829-832.

McEvilly, R.J. and M.G. Rosenfeld. 1997. Genetically defined roles of class I, III and IV POU domain factors in the development of the mammalian endocrine and nervous systems. Curr. Opin. Endocrinol. Diabetes 4: 172-183.

McEvilly, R.J., L. Erkman, L. Luo, P.E. Sawchenko, A.F. Ryan, and M.G. Rosenfeld. 1996. Requirement for Brn-3.0 in differentiation and survival of sensory and motor neurons. $\mathrm{Na}$ ture 384: 574-577.

Meijer, D., A. Graus, R. Kraay, A. Langeveld, M.P. Mulder, and G. Grosveld. 1990. The octamer binding factor Oct6: cDNA cloning and expression in early embryonic cells. Nucleic Acids Res. 18: 7357-7365.

Minucci, S., V. Botquin, Y.I. Yeom, A. Dey, I. Sylvester, D.J. Zand, K. Ohbo, K. Ozato, and H.R. Scholer. 1996. Retinoic acid-mediated down-regulation of Oct $3 / 4$ coincides with the loss of promoter occupancy in vivo. EMBO J. 15: 888-899.

Misra, V., S. Walter, P. Yang, S. Hayes, and P. O'Hare. 1996. Conformational alteration of Oct-1 upon DNA binding dictates selectivity in differential interactions with related transcriptional coactivators. Mol. Cell. Biol. 16: 4404-4413.

Monuki, E.S., G. Weinmaster, R. Kuhn, and G. Lemke. 1989. SCIP: A glial POU domain gene regulated by cyclic AMP. Neuron 3: 783-793.

Monuki, E.S., R. Kuhn, G. Weinmaster, B.D. Trapp, and G. Lemke. 1990. Expression and activity of the POU transcription factor SCIP. Science 249: 1300-1303.

Monuki, E.S., R. Kuhn, and G. Lemke. 1993. Repression of the myelin P0 gene by the POU transcription factor SCIP. Mech. Dev. 42: 15-32.

Morita, E.H., M. Shirakawa, F. Hayashi, M. Imagawa, and Y. Kyogoku. 1995. Structure of the Oct-3 POU-homeodomain in solution, as determined by triple resonance heteronuclear multidimensional NMR spectroscopy. Protein Sci. 4: 729739 . 
Müller, M.M., S. Ruppert, W. Schaffner, and P. Matthias. 1988. A cloned octamer transcription factor stimulates transcription from lymphoid-specific promoters in non-B cells. $\mathrm{Na}$ ture 336: 544-551.

Nakai, S., H. Kawano, T. Yudate, M. Nishi, J. Kuno, A. Nagata K. Jishage, H. Hamada, H. Fujii, K. Kawamura, K. Shiba, and T. Noda. 1995. The POU domain transcription factor Brn-2 is required for the determination of specific neuronal lineages in the hypothalamus of the mouse. Genes \& Dev. 9: 3109-3121.

$\mathrm{Ng}, \mathrm{M} .$, F.J. Diaz-Benjumea, and S.M. Cohen. 1995. nubbin encodes a POU-domain protein required for proximal-distal patterning in the Drosophila wing. Development 121: 589-599.

Ng, M., F.J. Diaz-Benjumea, J-P. Vincent, J. Wu, and S.M. Cohen. 1996. Specification of the wing by localized expression of the wingless protein. Nature 381: 316-318.

Nielsen, P.J., O. Georgiev, B. Lorenz, and W. Schaffner. 1996. B lymphocytes are impaired in mice lacking the transcriptional co-activator Bob1/OCA-B/OBF1. Euro. I. Immun. 26: 3214-3218.

Ninkina, N.N., G.E. Stevens, J.N. Wood, and W.D. Richardson. 1993. A novel Brn3-like POU transcription factor expressed in subsets of rat sensory and spinal cord neurons. Nucleic Acids Res. 21: 3175-3182.

Ohno, H., S. Goto, S. Taki, T. Shirasawa, H. Nakano, S. Miyatake, T. Aoe, Y. Ishida, H. Maeda, T. Shirai, K. Rajewsky, and T. Saito. 1994. Targeted disruption of the CD3 eta locus causes high lethality in mice: Modulation of Oct- 1 transcription on the opposite strand. EMBO I. 13: 1157-1165.

Okamoto, K., M. Wakamiya, S. Noji, E. Koyama, S. Taniguchi, R. Takemura, N.G. Copeland, D.J. Gilbert, N.A. Jenkins, M. Muramatsu, M. Muramatsu, and H. Hamada. 1993. A novel class of murine POU gene predominantly expressed in central nervous system. I. Biol. Chem. 268: 7449-7457.

Okazawa, H., I. Imafuku, M.T. Minowa, I. Kanazawa, H. Hamada, and M.M. Mouradian. 1996. Regulation of striatal D1A dopamine receptor gene transcription by Brn-4. Proc. Nat1. Acad. Sci. 93: 11933-11938.

Pfaffle, R.W., G.E. DiMattia, J.S. Parks, M.R. Brown, J.M. Wit, M. Jansen, H. Van der Nat, J.L. Van den Brande, M.G. Rosenfeld, and H.A. Ingraham. 1992. Mutation of the POU-specific domain of Pit-1 and hypopituitarism without pituitary hypoplasia. Science 257: 1118-1121.

Pfisterer, P., S. Zwilling, J. Hess, and T. Wirth. 1995. Functional characterization of the murine homolog of the B cell-specific coactivator BOB.1/OBF.1. J. Biol. Chem. 270: 29870-29880.

Pfisterer, P., H. Konig, J. Hess, G. Lipowsky, B. Haendler, W.D. Schleuning, and T. Wirth. 1996. CRISP-3, a protein with homology to plant defense proteins, is expressed in mouse B cells under the control of Oct2. Mol. Cell. Biol. 16: 61606168.

Prakash, K., X.D. Fang, D. Engelberg, A. Behal, and C.S. Parker. 1992. dOct2, a Drosophila Oct transcription factor that functions in yeast. Proc. Nat1. Acad. Sci. 89: 7080-7084.

Radovick, S., M. Nations, Y. Du, L.A. Berg, B.D. Weintraub, and F.E. Wondisford. 1992. A mutation in the POU-homeodomain of Pit-1 responsible for combined pituitary hormone deficiency. Science 257: 1115-1118.

Renner, K., H. Leger, and M. Wegner. 1994. The POU domain protein Tst-1 and papovaviral large tumor antigen function synergistically to stimulate glia-specific gene expression of JC virus. Proc. Nat1. Acad. Sci. 91: 6433-6437.

Rhodes, S.J., R. Chen, G.E. DiMattia, K.M. Scully, K.A. Kalla, S.C. Lin,V.C. Yu, and M.G. Rosenfeld. 1993. A tissue-specific enhancer confers Pit-1-dependent morphogen inducibility and autoregulation on the pit-1 gene. Genes \& Dev.
7: 913-932.

Rosner, M.H., M.A. Vigano, K. Ozato, P.M. Timmons, F. Poirier, P.W. Rigby, and L.M. Staudt. 1990. A POU-domain transcription factor in early stem cells and germ cells of the mammalian embryo. Nature 345: 686-692.

Sampath, K. and G.W. Stuart. 1996. Developmental expression of class III and IV POU domain genes in the zebrafish. Biochem. Biophys. Res. Comm. 219: 565-571.

Scheidereit, C., J.A. Cromlish, T. Gerster, K. Kawakami, C.G. Balmaceda, R.A. Currie, and R.G. Roeder. 1988. A human lymphoid-specific transcription factor that activates immunoglobulin genes is a homoeobox protein. Nature 336: 551557.

Scherer, S.S., D.Y. Wang, R. Kuhn, G. Lemke, L. Wrabetz, and J. Kamholz. 1994. Axons regulate Schwann cell expression of the POU transcription factor SCIP. J. Neurosci. 14: 19301942.

Schöler, H.R., S. Ruppert, N. Suzuki, K. Chowdhury, and P. Gruss. 1990. New type of POU domain in germ line-specific protein Oct-4. Nature 344: 435-439.

Schöler, H.R., T. Ciesiolka, and P. Gruss. 1991. A nexus between Oct-4 and E1A: Implications for gene regulation in embryonic stem cells. Cell 66: 291-304.

Schonemann, M.D., A.K. Ryan, R.J. McEvilly, S.M. O'Connell C.A. Arias, K.A. Kalla, P. Li, P.E. Sawchenko, and M.G. Rosenfeld. 1995. Development and survival of the endocrine hypothalamus and posterior pituitary gland requires the neuronal POU domain factor Brn-2. Genes \& Dev. 9: 31223135.

Schubart, D.B., A. Rolink, M.H. Kosco-Vilbois, F. Botteri, and P. Matthias. 1996. B-cell-specific coactivator OBF-1/OCA-B/ Bobl required for immune response and germinal centre formation. Nature 383: 538-542.

Segil, N., S.B. Roberts, and N. Heintz. 1991. Mitotic phosphorylation of the Oct-1 homeodomain and regulation DNA bind ing activity. Science 254: 1814-1816.

Seidah, N.G., J.C. Barale, M. Marcinkiewicz, M.G. Mattei, R. Day, and M. Chretien. 1994. The mouse homeoprotein mLIM-3 is expressed early in cells derived from the neuroepithelium and persists in adult pituitary. DNA Cell Biol. 13: $1163-1180$.

Simmons, D.M., J.W. Voss, H.A. Ingraham, J.M. Holloway, R.S Broide, M.G. Rosenfeld, and L.W. Swanson. 1990. Pituitary cell phenotypes involve cell-specific Pit-1 mRNA translation and synergistic interactions with other classes of transcription factors. Genes \& Dev. 4: 695-711.

Sivaraja, M., M.C. Botfield, M. Mueller, A. Jancso, and M.A. Weiss. 1994. Solution structure of a POU-specific homeodomain: 3D-NMR studies of human B-cell transcription factor Oct-2. Biochemistry 33: 9845-9855.

Sock, E., K. Renner, D. Feist, H. Leger, and M. Wegner. 1996. Functional comparison of PML-type and archetype strains of JC virus. J. Virol. 70: 1512-1520.

Sornson, M.W., W. Wu, J.S. Dasen, S.E. Flynn, D.J. Norman, S.M. O'Connell, I. Gukovsky, C. Carriere, A.K. Ryan, A.P. Miller, L. Zuo, A.S. Glieberman, B. Andersen, W.G. Beamer, and M.G. Rosenfeld. 1996. Pituitary lineage determination by the Prophet of Pit-1 homeodomain factor defective in Ames dwarfism. Nature 384: 327-333.

Spaniol, P., C. Bornmann, G. Hauptmann, and T. Gerster. 1996. Class III POU genes of zebrafish are predominantly expressed in the central nervous system. Nucleic Acids Res. 24: 4874-4881.

Staudt, L.M. and M.J. Lenardo. 1991. Immunoglobulin gene transcription. Annu. Rev. Immunol. 9: 373-398.

Stern, S. and W. Herr. 1991. The herpes simplex virus trans- 
activator VP16 recognizes the Oct-1 homeo domain: Evidence for a homeo recognition subdomain. Genes \& Dev. 5:2555-2566.

Strubin, M., J.W. Newell, and P. Matthias. 1995. OBF-1, a novel B cell-specific coactivator that stimulates immunoglobulin promoter activity through association with octamer-binding proteins. Cell 80: 497-506.

Sturm, R.A. and W. Herr. 1988. The POU domain is a bipartite DNA-binding structure. Nature 336: 601-604.

Sturm, R.A., G. Das, and W. Herr. 1988. The ubiquitous octamer-binding protein Oct-1 contains a POU domain with a homeo box subdomain. Genes \& Dev. 2: 1582-1599.

Suzuki, N., H. Rohdewohld, T. Neuman, P. Gruss, and H.R. Scholer. 1990. Oct-6: A POU transcription factor expressed in embryonal stem cells and in the developing brain. $E M B O$ I. 9: 3723-3732.

Szeto, D.P., A.K. Ryan, S.M. O'Connell, and M.G. Rosenfeld. 1996. P-OTX: A Pit-1 interacting homeodomain factor expressed during anterior pituitary gland development. Proc. Natl. Acad. Sci. 93: 7706-7710.

Takeda, H., T. Matsuzaki, T. Oki, T. Miyagawa, and H. Amanuma. 1994. A novel POU domain gene, zebrafish pou2: Expression and roles of two alternatively spliced twin products in early development. Genes \& Dev. 8: 45-59.

Turner, E.E., K.J. Jenne, and M.G. Rosenfeld. 1994. Brn-3.2: A Brn-3-related transcription factor with distinctive central nervous system expression and regulation by retinoic acid. Neuron 12: 205-218.

Verrijzer, C.P. and P.C. Van der Vliet. 1993. POU domain transcription factors. Biochim. Biophys. Acta 1173: 1-21.

Verrijzer, C.P., A.J. Kal, and P.C. Van der Vliet. 1990. The Oct-1 homeo domain contacts only part of the octamer sequence and full Oct-1 DNA-binding activity requires the POU-specific domain. Genes \& Dev. 4: 1964-1974.

Verrijzer, C.P., M.J. Alkema, W.W. van Weperen, H.C. Van Leeuwen, M.J. Strating, and P.C. van der Vliet. 1992. The DNA binding specificity of the bipartite POU domain and its subdomains. EMBO T. 11: 4993-5003.

Vigano, M.A. and L.M. Staudt. 1996. Transcriptional activation by Oct-3: Evidence for a specific role of the POU-specific domain in mediating functional interaction with Oct-1. Nucleic Acids Res. 24: 2112-2118.

Walker, S., S. Hayes, and P. O'Hare. 1994. Site-specific conformational alteration of the Oct-1 POU domain-DNA complex as the basis for differential recognition by Vmw65 (VP16). Cell 79: 841-852.

Way, J.C. and M. Chalfie. 1988. mec-3, a homeobox-containing gene that specifies differentiation of the touch receptor neurons in C. elegans. Cell 54: 5-16.

Wegner, M., D.W. Drolet, and M.G. Rosenfeld. 1993a. POUdomain proteins: Structure and function of developmental regulators. Curr. Opin. Cell Biol. 5: 488-498.

- 1993b. Regulation of JC virus by the POU-domain transcription factor Tst-1: Implications for progressive multifocal leukoencephalopathy. Proc. Nat1. Acad. Sci. 90: 47434747.

Weinstein, D.E., P.G. Burrola, and G. Lemke. 1995. Premature Schwann cell differentiation and hypermyelination in mice expressing a targeted antagonist of the POU transcription factor SCIP. Mol. Cell. Neurosci. 6: 212-229.

Wey, E., G.E. Lyons, and B.W. Schafer. 1994. A human POU domain gene, mPOU, is expressed in developing brain and specific adult tissues. Eur. J. Biochem. 220: 753-762.

Whitfield, T., J. Heasman, and C. Wylie. 1993. XLPOU-60, a Xenopus POU-domain mRNA, is oocyte-specific from very early stages of oogenesis, and localised to presumptive me- soderm and ectoderm in the blastula. Dev. Biol. 155: 361370.

- 1995. Early embryonic expression of XLPOU-60, a Xenopus POU-domain protein. Dev. Biol. 169: 759-769.

Witta, S.E. and S.M. Sato. 1997. XLPOU2 is a potential regulator of Spemann's organizer. Development 124: 1179-1189.

Witta, S.E., V.R. Agarwal, and S.M. Sato. 1995. XLPOU2, a noggin-inducible gene, has direct neuralizing activity. Development 121: 721-730.

Xiang, M., L. Zhou, Y.W. Peng, R.L. Eddy, T.B. Shows, and J. Nathans. 1993. Brn-3b: A POU domain gene expressed in a subset of retinal ganglion cells. Neuron 11: 689-701.

Xiang, M., L. Zhou, J.P. Macke, T. Yoshioka, S.H. Hendry, R.L. Eddy, T.B. Shows, and J. Nathans. 1995. The Brn-3 family of POU-domain factors: Primary structure, binding specificity, and expression in subsets of retinal ganglion cells and somatosensory neurons. J. Neurosci. 15: 4762-4785.

Xiang, M., L. Gan, L. Zhou, W.H. Klein, and J. Nathans. 1996. Targeted deletion of the mouse POU domain gene Brn-3a causes selective loss of neurons in the brainstem and trigeminal ganglion, uncoordinated limb movement, and impaired suckling. Proc. Natl. Acad. Sci. 93: 11950-11955.

Xue, D., M. Finney, G. Ruvkun, and M. Chalfie. 1992. Regulation of the mec-3 gene by the $C$. elegans homeoproteins UNC-86 and MEC-3. EMBO I. 11: 4969-4979.

Xue, D., Y. Tu, and M. Chalfie. 1993. Cooperative interactions between the Caenorhabditis elegans homeoproteins UNC86 and MEC-3. Science 261: 1324-1328.

Yang, X., S. Yeo, T. Dick, and W. Chia. 1993. The role of a Drosophila POU homeo domain gene in the specification of neural precursor cell identity in the developing embryonic central nervous system. Genes \& Dev. 7: 504-516.

Yeo, S.L., A. Lloyd, K. Kozak, A. Dinh, T. Dick, X. Yang, S. Sakonju, and W. Chia. 1995. On the functional overlap between two Drosophila POU homeo domain genes and the cell fate specification of a CNS neural precursor. Genes \& Dev. 9: 1223-1236.

Yeom, Y.I., G. Fuhrmann, C.E. Ovitt, A. Brehm, K. Ohbo, M. Gross, K. Hübner, and H.R. Schöler. 1996. Germline regulatory element of oct- 4 specific for the totipotent cycle of embryonal cells. Development 122: 881-894.

Zhadanov, A.B., S. Bertuzzi, M. Taira, I.B. Dawid, and H. Westphal. 1995. Expression pattern of the murine LIM class homeobox gene Lhx3 in subsets of neural and neuroendocrine tissues. Dev. Dynam. 202: 354-364.

Zhou, H., T. Yoshioka, and J. Nathans. 1996. Retina-derived POU-domain factor-1: A complex POU-domain gene implicated in the development of retinal ganglion and amacrine cells. J. Neurosci. 16: 2261-2274.

Zwart, R., L. Broos, G. Grosveld, and D. Meijer. 1996. The restricted expression pattern of the POU factor Oct-6 during early development of the mouse nervous system. Mech. Dev. 54: 185-194.

Zwilling, S., H. Konig, and T. Wirth. 1995. High mobility group protein 2 functionally interacts with the POU domains of octamer transcription factors. EMBO J. 14: 1198-1208. 


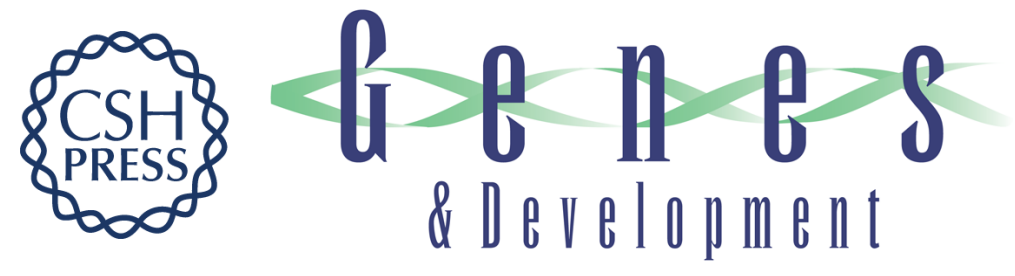

\section{POU domain family values: flexibility, partnerships, and developmental codes.}

A K Ryan and M G Rosenfeld

Genes Dev. 1997, 11:

Access the most recent version at doi:10.1101/gad.11.10.1207

References This article cites 182 articles, 86 of which can be accessed free at:

http://genesdev.cshlp.org/content/11/10/1207.full.html\#ref-list-1

License

Email Alerting

Service

Receive free email alerts when new articles cite this article - sign up in the box at the top right corner of the article or click here.

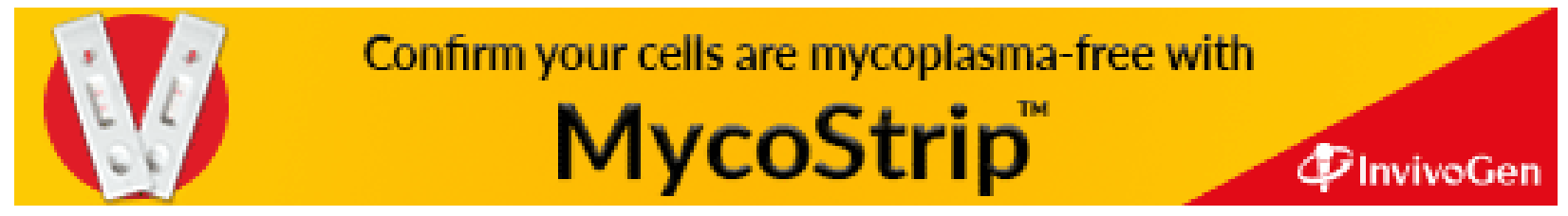

